American University Washington College of Law

Digital Commons @ American University Washington College of

Law

Articles in Law Reviews \& Other Academic Journals

Scholarship \& Research

1993

Two Sherman Act Section 1 Dilemmas: Parallel Pricing, the Oligopoly Problem, and Contemporary Economic Theory

Jonathan Baker

Follow this and additional works at: https://digitalcommons.wcl.american.edu/facsch_lawrev

Part of the Antitrust and Trade Regulation Commons, Evidence Commons, and the Law and Economics Commons 


\section{Two Sherman Act section 1 dilemmas: parallel pricing, the oligopoly problem, and contemporary economic theory}

BY JONATHAN B. BAKER*

The prohibition most fundamental to Sherman Act $\S 1^{1}$ bars an agreement on price among competitors. ${ }^{2}$ Such an agreement is

* Special Assistant to the Deputy Assistant Attorney General for Economics, Antitrust Division, U.S. Department of Justice.

AUTHOR'S NOTE: The author is indebted to Joe Angland, Michael Asimow, Paul Denis, Lawrence DeMille-Wagman, Will Gillespie, Jay Hamilton, Ken Heyer, Donna Kooperstein, Bill Kovacic, M.J. Moltenbrey, Janusz Ordover, Steve Salop, Mark Schechter, Bobby Willig and Peter Woodward. The views expressed in this article are not necessarily those of these colleagues, nor of the U.S. Department of Justice. The author is grateful to the Duke University School of Law and the John M. Olin Foundation, Inc. for support, and to Natalie Jackvony for research assistance.

1 Section 1 of the Sherman Act prohibits every "contract, combination . . . , or conspiracy" in restraint of trade. 15 U.S.C. \& 1 (1988).

2 Horizontal restraints on price are illegal per se unless they are ancillary to an economic integration generating a large cost savings or other efficiency, tantamount to the creation of a new product. Those 
akin to the very trusts (cartels) that the antitrust laws were intended to prohibit. Through a horizontal agreement to fix price, competitors may act collectively as would a monopolist, creating the identical harm to competition and consumers.

Perhaps the most difficult issue in applying $\S 1$, from both a legal and economic perspective, is identifying an agreement among competitors to fix prices when the evidence of agreement is entirely circumstantial. ${ }^{3}$ In particular, courts and commentators have debated for decades whether parallel price changes by oligopolists who recognize their interdependence provide a sufficient basis for a court to infer an unlawful horizontal agreement under Sherman Act $\S 1$, and if not what additional circumstantial evidence is required to prove a conspiracy. ${ }^{4}$ Parallel pricing cases challenge courts to distinguish between unilateral and concerted conduct. $^{5}$

The difficult issue of proving an agreement to fix prices from parallel pricing and other circumstantial evidence is at the core of

restraints that do not fall within the per se prohibition are illegal if unreasonable. See generally, Baker, Per Se Rules in the Antitrust Analysis of Horizontal Restraints, 36 ANTITRust Bull. 733 (1991).

3 When the evidence for an agreement is circumstantial, the fact of an agreement must be inferred even if the evidence is believed. Circumstantial evidence is distinguished from direct evidence of an agreement, such as the testimony of a remorseful conspirator that "we met and agreed to the following conduct" or a written memorialization of the agreement. Although direct evidence may be contradicted by other evidence or challenged as to credibility, it resolves a matter at issue if believed. In contrast, additional inference is required to resolve the matter at issue when the evidence offered is circumstantial. 1 McCoRMICK on EVIDENCE 777 (1992).

4 Although parallel pricing is the focus of this article, similar inferential issues arise with other forms of parallel conduct, such as parallel refusals by competitors to deal with a common customer or supplier.

5 The Supreme Court has termed this distinction "basic" to the Sherman Act. Copperweld Corp. v. Independence Tube Corp., 467 U.S. 752, 767 (1984) citing Monsanto Co. v. Spray-Rite Serv. Corp., 465 U.S. 752, 761 (1984); accord, United States v. Colgate \& Co., 250 U.S. 300, 307 (1919). 
antitrust's longstanding efforts to attack the "oligopoly problem." This term refers to the concern that an industry characterized by a small number of sellers will exercise market power. During the 1950s and 1960s, when the structural school of antitrust analysis was dominant, it was commonly thought that oligopolies would normally succeed in raising prices above competitive levels either through reaching a price-fixing agreement, or merely by interacting while recognizing their interdependence. The latter possibility, termed "tacit collusion," was thought to be nearly inevitable in oligopolies. Although antitrust law ultimately rejected the strategy of attacking the oligopoly problem by deeming "conscious parallelism" in prices to be an agreement in violation of Sherman Act $\S 1$, that proposal was widely debated.

In contrast, antitrust commentators writing from the more modern Chicago school perspective typically dismiss the possibility of noncompetitive behavior unless the firms actually cooperate. Under this view, the oligopoly problem is identical to the problem of uncovering and prosecuting price fixing. But interfirm coordination is not inevitable, and its likelihood depends upon certain structural characteristics of the industry that vary from one market to another. Since the mid-1970s, the Chicago approach to antitrust has come to dominate courts and commentary, ${ }^{6}$ the term "tacit collusion" has come to mean no more than an agreement proved through circumstantial evidence, ${ }^{7}$ and an economic analy-

6 See generally, e.g., Calvani \& Silbarium, Antitrust Today: Maturity or Decline, 35 AntrrRust Bull. 123 (1990); Baker, Recent Developments in Economics That Challenge Chicago School Views, 58 ANTITRUST L.J. 645, 645 n.1 (1989); Baker, Book Review, 34 ANTITRust Bull. 919 (1989).

7 Kovacic, The Identification and Proof of Horizontal Agreements Under the Antitrust Laws, 38 ANTITRust Bull. 5 (1993), at text accompanying note 51. As a matter of logic, an express agreement (in which the parties provide each other with explicit assurances, usually verbal, that they will carry out their promises) proved through circumstantial evidence is not the same as a tacit understanding (in which no such assurances are given). See Esco Corp. v. United States, 340 F.2d 1000, 1007 (9th Cir. 1965) ("[a] knowing wink can mean more than words"); R. PosNER, ANTITRUST LAW 72 (1976) (in tacit collusion, "one seller communi- 
sis of the structural features of the industry environment that make coordination more or less plausible has become relevant to the determination of whether an agreement exists in a parallel pricing case.

This article highlights the implications of theoretical and empirical developments in economics since the rise of the Chicago school for the way antitrust addresses the oligopoly problem. Section I describes the way economists understand oligopoly behavior today. This section explains that the most important contemporary economic development for Sherman Act $\S 1$ jurisprudence is the recognition that, in an economic environment conducive to coordination, an agreement in the legal sense will often be unnecessary for coordination to occur. As will be seen, this insight creates two serious dilemmas for antitrust policy.

The first dilemma, set forth in section II of this article, arises in the application of Sherman Act $\S 1$ in parallel pricing cases. The dilemma points out the way insights from contemporary economic theory can discourage courts from inferring agreements to fix price. The first horn of the dilemma emerges from the observation that if the industry's economic environment is not conducive to coordination, it will be irrational for the firms to engage in the process of negotiating a common understanding and exchanging

cates his 'offer' by reducing output, and the offer is 'accepted' by the actions of his rivals in restricting output as well"). Because a tacit agreement is not logically identical to an agreement proved with circumstantial evidence, it is possible to imagine having circumstantial evidence of an express agreement (e.g., the parties met in a hotel room one day and raised price the next), or direct evidence of a tacit agreement (e.g., the manager of each firm involved testifies that the firms reached an agreement through the exchange of advance announcements of price increases). Nevertheless, it is appropriate to apply a single legal standard to identify an agreement under Sherman Act \& 1, regardless of whether the agreement is tacit or express, because a tacit agreement to fix price and a concealed express agreement will look the same to a judge or jury. Posner, Oligopoly and the Antitrust Laws: A Suggested Approach, 21 STAN. L. Rev. 1562, 1575 (1969); see Yao \& DeSanti, Game Theory and the Legal Analysis of Tacit Collusion, 38 ANTrrRust Bull. 113 (1993), at text accompanying notes 38-39 (from the perspective of game theory, there is no distinction between tacit and express collusion). 
mutual assurances that the law terms an agreement. A court that recognizes that coordination is implausible for this reason will be slow to construe circumstantial evidence as demonstrating an agreement. If instead an economic analysis demonstrates that the industry is fertile ground for coordination, the second horn of the dilemma appears. In an environment conducive to coordination, collective decision making supported by the exchange of assurances of compliance (i.e., an agreement) may be unnecessary for the industry to reach a coordinated marketplace outcome. If the observed market outcomes are consistent with what coordinating firms could reach absent an agreement, as may often be the case, then a court may reasonably conclude that it would be irrational for the sellers to risk antitrust liability by agreeing. As courts come to recognize the second horn of this dilemma, they will experience a reluctance to infer an agreement in many industries in which the economic environment is conducive to effective coordination, in the absence of direct evidence that the firms agreed. Whether the economic environment is conducive to coordination or not, the first dilemma suggests that courts will become more reluctant to infer an agreement to fix price from circumstantial evidence including parallel pricing.

The second dilemma for antitrust policy, discussed in section III of this article, emerges from the first dilemma. On the one hand, the first dilemma implies that it is likely to become more difficult to prove an agreement from circumstantial evidence. On the other hand, contemporary economics suggests that it has become more important for antitrust to address oligopoly behavior than previously thought. Coordinated behavior, leading to higher than competitive prices, while not inevitable, will nevertheless occur even under circumstances in which reaching a price-fixing agreement would be irrational. Oligopolies may in consequence exercise market power under circumstances in which Chicago-oriented commentators would find that result unlikely.

This dilemma returns the oligopoly problem to the center of contemporary debates over antitrust policy. As antitrust's traditional tool for attacking the oligopoly problem-proving an agreement under Sherman Act $\S 1$-has been blunted through the 
operation of the first dilemma, the problem itself has simultaneously come to appear more serious. Through the operation of the second dilemma, recent developments in economics imply that the oligopoly problem is simultaneously less tractable through prosecution under Sherman Act $\S 1$ and more troublesome for the economy than is recognized by the Chicago-oriented antitrust mainstream.

A concluding section of this article, section IV, suggests two ways of addressing the oligopoly lacuna in antitrust enforcement. The first remedial approach involves merger enforcement. The prohibition against anticompetitive mergers has long been understood as aimed in large part at preventing mergers likely to enhance coordination. Merger enforcement has traditionally applied a broad brush to that task: antitrust enforcers and courts typically presume that the coordination becomes more likely or more effective when concentration increases significantly in those oligopolies with a market structure conducive to coordination. Although contemporary economic theory does not undermine the statistical prediction on which the traditional presumption is based, contemporary economics does promise to permit courts and enforcers examining acquisitions to differentiate, in many cases, those mergers that are likely to make coordination worse from other mergers likely to destabilize coordination. To the extent such discrimination is possible, enforcers can improve their ability to target merger enforcement to address the oligopoly problem.

The second approach to attacking the oligopoly problem involves the increased use of Federal Trade Commission rulemaking to prohibit practices facilitating oligopoly coordination. This remedial approach can be employed regardless of whether the challenged practices have been adopted unilaterally or through concerted action. 
I. The oligopoly problem in contemporary economic theory

Industrial organization economists and antitrust commentators writing in the tradition of the structural school, the dominant approach in the 1950 s and 1960 s, typically argued that parallel pricing by oligopolists could be expected to result in high prices comparable to what the firms would achieve were the firms not forbidden by Sherman Act $\S 1$ from cartelizing expressly. In an oligopoly setting, ${ }^{8}$ each firm necessarily pays attention to the price and output decisions of its rivals. Each firm is aware that its rivals will react to any change in price or output it makes; the industry interacts under conditions of oligopolistic interdependence. As a result, in the view of commentators at mid-century, the firms will likely be led to behave less aggressively toward each other than they would were they competing with a large number of rivals. Less aggressive firm behavior limits the competitive pressure on prices, and, in consequence, can be expected to generate prices above those that would lead firms to earn merely the economic profits that competition would allow. This reasoning suggests that higher than competitive prices are nearly inevitable in oligopolies. ${ }^{9}$

8 The oligopolies considered in this article are presumed to be sufficiently stable to make plausible the repeated interaction implicit in the idea of interdependence. Although this assumption will plausibly characterize many if not most oligopolies, it is least likely to hold when significant new competition (e.g., through large-scale entry, or through a major expansion or innovation by an incumbent) is frequent or imminent, because a new competitor may prefer competition to any plausible coordinated understanding. See infra at note 117.

9 Edward Chamberlin argued that each oligopolist will be reluctant to cut price because it recognizes that its rivals will match. "Since the result of a cut by any one is inevitably to decrease his own profits, no one will cut, and although the sellers are entirely independent, the equilibrium result is the same as though there were a monopolistic agreement between them." E. Chamberlin, The Theory of Monopolistic CompetiTION 48 (1933). Many commentators took from Chamberlin the lesson that supracompetitive prices were nearly inevitable in oligopolies. See generally, G. Hale \& R. Hale, Market Power: Size and Shape Under THE SHERMAN ACT 122-23, 131-37 (1958). 
In 1964, George Stigler, a University of Chicago professor who would later win a Nobel Prize in economics, published an extremely influential economic article implicitly challenging the view that supracompetitive oligopoly pricing is nearly inevitable. ${ }^{10}$ Stigler profoundly changed the way economists understand coordination among oligopolists; ${ }^{11}$ and his analysis has also influenced antitrust law. ${ }^{12}$

Stigler's primary contribution was to point out that cooperating firms must do more than merely identify the terms of their understanding; they must also maintain their consensus against the incentives of firms to deviate from it (cheat). Often a firm can increase the quantity it sells dramatically by undercutting the cooperative price slightly. Even though the firm must accept a lower price to achieve this result, it may find the temptation irresistible when the lower price remains in excess of cost. The firm may well prefer to receive a substantial increase in the quantity sold, albeit while earning a slightly lower price-cost margin on

10 Stigler, A Theory of Oligopoly, 72 J. PoL. Econ. 44 (1964).

11 E.g., Shapiro, Theories of Oligopoly Behavior, in HaNDBooK of INDUSTRIAL ORganization 356-57 (R. Schmalensee \& R. Willig eds. 1989) (describing Stigler's "classic" article and terming Stigler's understanding of oligopoly behavior as a problem of policing a tacitly collusive arrangement as "now the norm"). Joe S. Bain, the leading industrial organization economist before Stigler, acknowledged that oligopolists may have an incentive to cut price in describing the oligopoly equilibrium as the result of "a counter-pull between joint profit-maximizing and independent profit-maximizing motives." J. BAIN, INDUSTRIAL ORGANIZATION 120 (2d ed. 1968). But Bain devoted little attention to this issue, and when he did address it, he noted that sellers often anticipate and address the incentive for independent price concessions by "the development of supplementary collusive uniformities (express or tacit)." Id. at 313. In contrast, Stigler's discussion elevates the issue of cartel policing to one of fundamental importance in determining whether an oligopoly can successfully raise prices.

12 One important vehicle through which Stigler's article entered the legal literature was Posner, supra note 7. For an example of the influence of Stigler on Chicago-oriented economic commentary on antitrust policy, see generally Y. Brozen, Concentration, Mergers, and Public Policy (1982). 
each unit than it would earn under the cooperative arrangement, to the alternative of complying with the terms of the understanding. Such a firm would prefer to compete rather than cooperate, and it would undercut any cooperative understanding with its rivals. Recognizing this prospect, its rivals may not find it worthwhile to cooperate in the first instance. Indeed, the unilateral incentive to deviate on a cooperative arrangement to fix price, highlighted by Stigler, is the very market force by which competition insures low prices and high output to the benefit of consumers and the economy.

Stigler's insight led to the recognition that it is far from inevitable that oligopolists behave noncompetitively. ${ }^{13}$ Under certain structural conditions, firms will have a powerful incentive to cheat on any cooperative understanding; if these conditions are present, cooperation is unlikely to persist (or to be achieved in the first instance). The following examples of such conditions are by no means exhaustive. ${ }^{14}$ Firms may have a strong incentive to cheat if captive production or nonprice competition permits them to increase sales secretly, ${ }^{15}$ if they can increase sales greatly by win-

13 Cf. Elzinga, New Developments on the Cartel Front, 29 ANTrTRust BuLl. 3, 6-7 (1984) (the lesson that collusion was not inevitable in oligopolies may also have been suggested by the complexity of the express agreement to fix prices uncovered in the electrical equipment industry around 1960).

14 A list of practices facilitating collusion has become a staple of both economics texts and antitrust monographs. See, e.g., F.M. SCHERER \& D. Ross, Industrial Market Structure and Economic Performance 235-315 (3d ed. 1990); D. Carlton \& J. PerLof, Modern Industrial. ORGANIZATION 208-38 (1990); R. POSNER, supra note 7, at 55-61.

15 See Ginsburg, Nonprice Competition, 38 ANTITRust Bull. 83 1993) (highlighting the significance of nonprice competition as a method of cheating on a horizontal agreement). But $c f$. Stigler, supra note 10 , at 56 ("[s]ome forms of non-price competition will be easier to detect than price-cutting because they leave visible traces (advertising, product quality, servicing, etc.) but some variants will be elusive (reciprocity in purchasing, patent licensing arrangements)"). For competition on nonprice dimensions to substitute completely for competition on price, the nonprice dimensions must, as a group, substitute perfectly for price from the 
ning a handful of contracts with large buyers, or if they can avoid the risk of punishment by their rivals through signing long-term contracts with buyers. Conversely, in order to maintain the terms of a consensus on price against the incentives of individual firms to deviate unilaterally, the cooperating firms must find ways of monitoring each other's compliance with their understanding, and credibly threatening to punish those who cheat on the deal. Only then will cooperating firms find it worthwhile to stick with the terms of their arrangement rather than deviate from it.

Developments in economic theory since Stigler's 1964 article have deepened the economic profession's understanding of oligopoly behavior. Stigler's identification of the three problems a cartel must solve in order to cooperate successfully-identifying the terms of the cooperative understanding, detecting deviation from those terms, and punishing that deviation-remains the cornerstone of the economic analysis of what is now termed coordination. ${ }^{16}$ Yet several important economic insights postdate

perspective of the marginal consumer of the product, and they must be as inexpensive for the firm to alter as price. Whether this is the case will turn on the facts of the individual industry.

16 The terminology employed by economists to describe the result of nonindependent decision making by firms has altered as economic theory has developed. Traditionally, economists described the joint decision and exchange of assurances by which a cartel is formed as "collusion" or "cooperation." In contrast, the term "noncooperative oligopoly behavior" was used to describe both competition (interactions in which firms earn no monopoly rents) and the supracompetitive pricing that may have resulted, without cooperation, when firms are aware that their rivals will react to their decisions. "Noncooperative oligopoly behavior" encompassed well known oligopoly solution concepts such as those of Cournot, Bertrand, and Stackelberg. In the legal debate from the 1950s and 1960s over "conscious parallelism," these noncooperative outcomes were thought likely to result from "mere oligopoly interdependence" (short of tacit or express collusion). Because the term "collusion" carries with it the legal idea of an agreement, this article will avoid that usage in discussing the older economic concept of cooperation, but employ the term when referring to the legal concepts of "express collusion" and "tacit collusion." The contemporary repeated game perspective on oligopoly behavior, has led some economists to speak of "coordination" rather than "cooperation," and this article adopts that usage. See Willig, Merger 
Stigler's pathbreaking analysis. As post-Stiglerian insights become as commonplace to courts as they are to economists, they will likely give force to the two antitrust policy dilemmas discussed in sections II and III of this article. The remainder of this section describes these contemporary economic insights into coordination.

\section{A. From one-shot games to repeated games}

Stigler discussed cooperation in terms of an economic model in which each firm makes only one decision: whether to cooperate or compete. This setting is termed a "one-shot game" in the contemporary language of economic theory. Stigler established the conditions under which each firm would prefer to cooperate rather than to compete. In the terminology of static oligopoly models, these are the conditions under which cooperation is a dominant strategy for every firm in the industry.

From a contemporary economic perspective, industry behavior is understood as emerging from a repeated game rather than from the one-shot game studied by Stigler. ${ }^{17}$ Firms often know they will interact with the same rivals again and again. Firms may in consequence base their present decisions on the way their rivals behaved in the past. Firms may also recognize that their current decisions may affect rival responses in the future, and thus influence future rewards. The outcome (equilibrium) of the repeated game is a path for prices and output from the present into the dis-

Analysis, Industrial Organization Theory, and Merger Guidelines, 1991 Brookings Papers on ECONOMIC ACTIVITY-Microeconomics 281, 292 (1991); 1992 Department of Justice and Federal Trade Commission Horizontal Merger Guidelines, 4 Trade Reg. Rep. (CCH) \& 13,104 \& 2.1 [hereinafter 1992 Merger Guidelines] (adopting the "coordinated" terminology). The term "coordinated" is defined infra at note 22.

17 In the repeated game models, also termed "oligopoly supergames," the game is repeated infinitely or else finitely with an uncertain termination point. Models in which games are repeated finitely with certain payoffs and certain termination dates are more similar to one-shot games than to the models discussed here. See generally, D. FuDENBERG \& J. Tirole, Game Theory 145-206 (1991). 
tant future, not a one-time outcome. Moreover, in repeated game settings, firm strategies may be more complex than the simple choice between cooperation and competition permissible in Stigler's one-shot game. ${ }^{18}$ For example, in the coordinated equilibria of repeated games, firms may cooperate for a while, cut price for a while, then cooperate again. As a result, industry prices may vary over time in a complex pattern.

Perhaps the most striking result of viewing oligopoly behavior through the lens of repeated games is one of the most basic: the so-called folk theorem. ${ }^{19}$ The folk theorem takes as given the same oligopoly setting that Stigler studied. In this setting, the firms can each profit during any period by simultaneously charging a high price, in excess of the competitive price. This price will be termed the "cartel price." But each firm has a strong incentive to cheat. It knows that if its rivals charge the cartel price, while it undercuts them, it will earn even greater profits than it would garner by going along with the cartel price. The slight reduction in price will allow the firm to increase the quantity it sells substantially without markedly lowering its per unit revenues or profits. Moreover, cheating by one seller is very costly for the rival firms that continue to charge the cartel price. When one firm cheats, its rivals will do worse by continuing to charge the cartel price than they would if they instead charge a lower, competitive price. ${ }^{20}$

Stigler studied a single interaction among the firms in this setting. He concluded that every firm will choose the competitive

18 The older oligopoly models that rely on one-shot games remain possible equilibria of a limiting case of the repeated game models in which firms interact each period without considering the past or future.

19 The term "folk theorem" is employed because this result was widely conjectured before it was formally demonstrated. Although there are multiple folk theorems in game theory, the folk theorem for infinitely repeated games with observable actions, discussed in the text, is typically termed "the" folk theorem. For a technical discussion and proof, see D. FUDENBERG \& J. TIROLE, supra note 17, at 152-54.

20 The single period (stage game) oligopoly payoffs in this setting are those characteristic of a "prisoner's dilemma." 
price. Each firm does so because it recognizes that its rivals have a strong incentive to cheat, and that cheating by a rival is very costly to a firm that does not compete. In this articulation of Stigler's story, the incentives to cheat on a cartel deter cooperation in the first place.

Now suppose that the firms interact as described above repeatedly, forever, and that they recognize that their interaction is repeated. The repetition of the game can change the outcome. A firm that cheats must now trade off the short-run gains from cheating against the now-larger cost. The cost of cheating is that the cheater will never receive the cartel price in the future; burned once, the cheater's rivals will never agree to the cartel price again. So each firm sees the following choice. It can cheat one time, then forever compete. Or, it can never cheat, in which case it will earn the cartel price forever. Unless the firm cares very little about future profits relative to present profits, it will prefer the second choice. It will never cheat on the cartel price. All firms have similar incentives, so each knows that none of its rivals will cheat on the cartel price. Recognizing that cheating will not occur, each firm charges the cartel price rather than the competitive price. ${ }^{21}$

21 Developments in economic theory since the folk theorem have demonstrated that cooperation continues to emerge in models after relaxing the assumption that once cheating occurs, the firms are never willing to choose a high price. The newer models permit any post-deviation behavior, so long as the conduct satisfies certain rationality criteria, such as: the proposed punishments must be credible; each firm must be willing to adopt a future strategy (such as charging a low price to punish a deviating rival) not only in prospect, but also when it comes time to implement the strategy; and the firms must be unwilling to renegotiate the equilibrium outcome once the game is underway. The more recent models also introduce various types of imperfect information and learning into the games. See generally, e.g., R. GibBons, GAME THEORY FOR APPLIED ECONOMISTS (1992); D. FUdENBERG \& J. TIROLE, supra note 17; D. KREPS, GAME TheORY AND Economic Modeluing (1990); Shapiro, supra note 11, at 329-414; Jacquemin \& Slade, Cartels, Collusion, and Horizontal Merger, in HaNDBOOK of Industriad. ORganization 416-73 (R. Schmalensee \& R. Willig eds. 1989). 
In this way, converting the standard oligopoly problem from a one-shot game to a repeated game can change the outcome. An oligopoly setting that appeared to encourage competition in Stigler's analysis may in fact permit supracompetitive pricing in the coordinated equilibrium outcome of a repeated game. ${ }^{22}$ As will be emphasized in the discussion of the second antitrust policy dilemma in section III below, from the perspective of contemporary economic theory, oligopoly has come to look more hospitable to supracompetitive pricing than it appeared from the Stiglerian viewpoint.

Stigler's core insights for antitrust policy nevertheless survive this change in economic perspective. In order to coordinate in repeated game models, firms must solve the three problems that Stigler identified: they must determine the terms of their coordinated arrangement, monitor deviation, and credibly threaten to punish deviation sufficiently in order to deter cheating in the first instance. ${ }^{23}$ By deepening the economic understanding of coordination, however, the contemporary economic perspective suggests

22 Contemporary economic theory distinguishes coordinated behavior from unilateral behavior. Unilateral behavior arises in repeated games when firms ignore the past and future, interacting in each period (stage game) as though it were a one-shot game. Hence any behavior in a oneshot game, whether cooperative or noncooperative, if infinitely repeated, would be considered unilateral from the perspective of an appropriate repeated game. Coordinated behavior arises when firms adopt, with or without discussion or communication with their rivals, strategies that recognize that they have interacted in the past and will continue to do so in the future. See Willig, supra note 16, at 292-93 \& 293 n.26; 1992 Merger Guidelines, supra note 16 , at $\$ 2.1$ (coordinating firms take actions that are profitable "only as a result of the accommodating actions of their rivals").

23 The 1992 Merger Guidelines emphasize the continuity of the modern economic perspective with the insights of Stigler in describing the conditions facilitating coordination. 1992 Merger Guidelines, supra note 16 , at $\S 2$. 
several additional insights of relevance to antitrust policy. Three of these insights are highlighted below: ${ }^{24}$

1. The threat of punishment must be credible in order to deter cheating.

2. Successful coordination will commonly be imperfect and incomplete.

3. When multiple outcomes are possible, as will often be the case in oligopoly settings, the choice of outcome turns on one of the possibilities becoming "focal."

\section{B. Punishments must be credible}

In contemporary economic models of coordination, firms do not deviate from high price outcomes because they fear the consequences of cheating. Each firm reasons that if it cheats, the shortterm benefit will be outweighed by a longer-term cost. Cheating is costly because the cheater's rivals do not stand idle once they have discovered the deviation. They punish the cheater by lowering the price. The rivals might merely return to competing, or they might engage in stronger punishment.

But the economic models insist that the rivals who do not cheat find it in their interest to punish if the time for punishment ever arises. ${ }^{25}$ It is not obvious that this would be so, as punishment can be costly to the firms undertaking it. For example, forc-

24 A fourth such insight, more relevant to merger analysis than to identifying horizontal agreements to fix price, is emphasized in section IV below in connection with the discussion of merger enforcement as a remedy for the oligopoly problem.

25 In the language of economic theory, this insight-that, no matter how attractive a future behavior appears today, firms will not be expected to follow it unless the conduct will be attractive when the time comes to adopt it-is termed the requirement of "subgame perfection." The commitments a firm makes in order to make credible the punishments it threatens in the event a rival cheats cause the equilibrium outcomes in which firms employ those punishment strategies to be subgame perfect. J. Tirole, The Theory of Industrial Organization 428-29 (1988); D. KREPS, supra note 21 , at 69 n.11. 
ing a cheater to experience a period of below-cost pricing would often constitute an extremely effective punishment. But if the market price is forced below cost in order to create such a punishment, the punishing firm will typically experience losses of its own. No matter how confidently the firm announces its intention to punish should some other firm cheat, when the time comes to carry through on that announcement, the firm may decide that preserving the coordinated outcome by engaging in below-cost pricing is more costly to it than its alternative option of accommodating the deviation by passively allowing the cheating to continue. Accordingly, if the cheating firm thinks that its rivals will not carry out a punishment threat, that threat will not deter the firm from deviating.

Firms can deter rivals from cheating by guaranteeing that when the time comes to carry through a punishment, they will find the punishment behavior attractive. They do so by tying their own hands, as through making irreversible (sunk) investments. ${ }^{26}$ For example, firms can acquire low cost excess capacity, thereby insuring that the punishment response of increased output will be attractive should a rival cheat. Or they might contractually obligate themselves to match any good faith low price offer of a rival, thereby insuring that they will lower their prices immediately should some rival cheat. Without some such commitment, a punishment threat more costly to the punishing firm than passively allowing (accommodating) the cheating will not be credible, cheating will not be deterred, and a cartel in which the high price outcome is guaranteed (supported) by that punishment threat cannot be successful. For this reason, in determining whether coordination is plausible, economists insist that the threatened punishments for deviation be credible.

26 For a discussion of these strategies generally, see Salop, Practices That (Credibly) Facilitate Oligopoly Coordination in New Developments in the Analysis of Market Structure 265-90 (J. Stiglitz \& G.F. Mathewson eds. 1986); Salop, Strategic Entry Deterrence, 69 AM. EcoN. REv. 335 (Papers \& Proceedings 1979). 
This development in economic understanding affects economic intuitions about the likelihood of successful coordination. The need for punishment to be credible confirms Stigler's emphasis on the difficulties involved in cooperation. The firms must punish cheating in order to deter deviation, but some potential punishment strategies will not suffice because such strategies must be credible. This insight into the difficulty of insuring cartel policing adds support to the Stiglerian view that coordination is not inevitable in oligopolies.

Yet the mere return to competition may constitute enough punishment to deter firms from cheating on some coordinated outcomes. ${ }^{27}$ In contrast to the threat of below-cost pricing, under which the firm engaging in punishment will suffer losses, the threat of returning to competition will frequently be a credible one. ${ }^{28} \mathrm{Hence}$, in the many industries in which some type of coordination can be maintained by the mere threat of the return to competition, the problem of cartel policing may not be fatal to reaching some coordinated outcome. Because coordination need not be perfect to be successful, as discussed below, the postStiglerian requirement that punishments be credible refines

27 E.g., Ross, Cartel Stability and Product Differentiation, 10 INT'L J. INDUS. ORG. 1 (1992) (the threat of a return to competition may credibly support coordination in a differentiated product setting). This point is recognized in the 1992 Merger Guidelines, supra note 16 , at $\S 2.12$ ("[c]redible punishment . . . may not need to be any more complex than temporary abandonment of the terms of coordination by other firms in the market").

28 Even though a return to competition does not cause the punishing firm to incur short-run losses, this strategy will not be credible unless it is more profitable for firms than the alternative strategy of passively allowing the cheating firm to deviate. When the cheating firm would expand output quickly, take a great deal of business from its rivals, and cause the market price to fall significantly, passive accommodation is unlikely to be more profitable than a return to competition. $C f$. Gelman \& Salop, Judo Economics: Capacity Limitations and Coupon Competition, 14 BELL J. EcoN. 315 (1983) (entrants, and by implication cheaters, can induce accommodation by their colluding rivals by committing to a strategy of limited entry). 
the economic understanding of what coordination requires without reducing the contemporary concern with the behavior of oligopolies.

\section{Coordination may be imperfect and incomplete}

The second insight arising from the shift in perspective from one-shot to repeated games is that coordination need not be perfect or complete in order to cause price to rise above the competitive level. As the 1992 Horizontal Merger Guidelines recognize, the terms of coordination may, for example, "omit some market participants, omit some dimensions of competition, omit some customers, yield elevated prices short of monopoly levels, or lapse into episodic price wars . . . and still result in significant competitive harm."29

In some sense, economists have never believed otherwise. The dominant view among economists writing in the pre-Stiglerian tradition, emphasizing the dangers of interdependent oligopoly behavior, was that most oligopolies engaged in behavior ranging between perfect cooperation and competition. ${ }^{30}$ Similarly, one leading Chicago school commentator, who took from Stigler the lessen that "oligopolists cannot be presumed always or often to charge supracompetitive prices," also "speculat[ed]" that Stigler's approach was not necessarily inconsistent with tacit coordination in some highly concentrated oligopolies "even if collusion was imperfect and the average price substantially below the joint maximizing price." 31 Nevertheless, economists writing in the wake of Stigler's article often accepted three generalizations: that mere interdependent behavior leads to little welfare loss without cooperation, that cooperation itself is unlikely because of the problems of reaching and policing agreements, but that should firms find a way to cooperate, the harm to competition would

\footnotetext{
291992 Merger Guidelines, supra note 16 , at $\S 2.11$.

30 E.g., J. BAIN, supra note 11, at 306-16.

31 Posner, supra note 7, at 1574.
} 
likely be substantial.32 Consequently, when the Justice Department became heavily influenced by Stigler, the agency placed a high priority on investigating and prosecuting criminal price-fixing conspiracies, ${ }^{33}$ and yet simultaneously was thought by commentators to have exhibited a relaxed concern that mergers would harm competition by making cooperation more likely. ${ }^{34}$

The Stiglerian perspective suggests a picture of the world in which firms are typically competing (or have achieved some other noncooperative oligopoly outcome). In such a world, the main concern of courts and enforcers would be that a structural change such as a merger or the introduction of a facilitating practice might tip the outcome (equilibrium) from competition to cooperation by altering every firm's dominant strategy. In contrast, the post-Stiglerian focus of economic theory on the requirement that punishments be credible suggests a different picture of the world, one in which coordination is typically incomplete or less than fully successful.

Economists now understand that the degree to which coordination can be successful depends upon the severity of the punishments the firms expect. The more successful cooperation becomes, the more the cooperating firms can benefit from cheating and the greater their incentive to do so. Hence, the more severe the punishment for cheating, the more successful cooperation can be. For example, the punishment of merely reverting to competition, which may often be a credible punishment, may

32 E.g., Bork, Antitrust and the Theory of Concentrated Markets, in Industrial Concentration and the Market System 81-89 (E. Fox \& J. Halverson eds. 1979); Y. BRozEN, supra note 12, at 181 (tacit collusion unlikely).

33 Rule, 60 Minutes with the Assistant Attorney General, Antitrust Division, 57 ANTrTRust L.J. 257, 258 (1988).

34 E.g., Briggs, An Overview of Current Law and Policy Relating to Mergers and Acquisitions, 56 ANTrTRust L.J. 657, 665, 670, 703 (1987); cf. 60 Minutes with Charles F. Rule, Assistant Attorney General, Antitrust Division, 58 Antitrust L.J. 377, 387 (1989) (denying the charge that merger standards were relaxed). 
frequently be sufficient to deter cheating if price rises somewhat above the competitive level, but not be sufficiently severe to deter cheating if price rises to the monopoly level. Yet the tougher punishments necessary to make coordination perfect or complete may not be credible; they may simply cost too much to those firms engaged in punishing their rivals.

From this contemporary perspective, incomplete and imperfect coordination is a plausible outcome in an oligopoly setting. ${ }^{35}$ Although the repeated game models preserve the Stiglerian insight that coordination is not inevitable, in the sense that the structural conditions making coordination irrational can be identified, the focus on incomplete and imperfect coordination creates a picture of the world more hospitable to coordination than has been suggested by those commentators most heavily influenced by Stigler.

\section{Focal rules may provide the terms of a coordinated understanding}

The third contemporary insight about oligopoly behavior arising from the perspective of the theory of repeated games is that many equilibrium outcomes are typically possible, ${ }^{36}$ and the choice of outcome turns on one of the possibilities standing out as self-evident. In the language of oligopoly theory, an outcome that stands out as self-evident is termed "focal." 37

35 See, e.g., Abreu, Extremal Equilibria of Oligopolistic Supergames, 39 J. ECON. THEORY 191 (1986); Green \& Porter, Noncooperative Collusion Under Imperfect Price Information, 52 ECONOMETRICA 87 (1984).

36 D. KREPS, supra note 21 , at 97.

37 Thomas Schelling, who invented the idea of focal points, recognized the idea's application to oligopoly coordination. T. ScHELLING, THE STRATEGY OF CONFICT 74 (1960) (oligopoly behavior is likely explained by "tacit communication and its dependence on qualitatively identifiable and fairly unambiguous signals that can be read in the situation itself"). In this article, the term "focal" is used in the general sense of a selfevident way to play the game, or a way of making one equilibrium stand out from among the many possibilities. See J. TIROLE, supra note 25 , at 
It is often easy for one outcome to stand out as self-evident, and, in consequence, for it to be selected as the equilibrium outcome. For example, one firm could announce its choice among possible outcomes at a press conference by saying "we intend to raise all prices by five percent next month." Such "cheap talk" (costless communication in the language of contemporary economic theory) may be all that is necessary for the industry members to identify one of the possibilities as the focal outcome, and, in consequence, for all to select it as the self-evident way to behave. ${ }^{38}$ To the extent it is easy to identify some terms of coordination in this way, the contemporary perspective suggests that it is typically the difficulties of policing a coordinated understanding (monitoring or punishing cheaters) rather than the difficulties of reaching the terms of that arrangement that potentially inhibits the possibility of coordination in most oligopolies. ${ }^{39}$

247. The term "focal" encompasses strategies that become self-evident because of negotiation, direct experience with the game, social convention, an obvious sense of correct play, and deduction and prospection. See D. Kreps, supra note 21 , at 139-44; D. KREPS, A COURSE IN MicroECONOMIC THEORY 410-17 (1990). Some economic theorists employ "refinements" of the equilibrium concept to isolate specific outcomes when multiple equilibria are possible. This analytic strategy identifies a way to play as self-evident through deduction from an arbitrary assumption of a higher degree of generality. See generally, D. KREPS, A COURSE IN MICROECONOMIC THEORY at 417-43. The resulting equilibria may be more focal to economic theorists than to the firms involved, however. See D. KREPS, supra note 21 , at 108 (expressing "skepticism" about the application of refinements); $c f$. K. BINMORE, Fun AND GAMES: A TEXT ON GAME THEORY 295 n.16, 544-45 (1992) (describing the subject of employing refinements as a basis for equilibrium selection as "controversial").

38 D. KREPs, supra note 37, at 388-89, 411; see, e.g., Farrell, Cheap Talk, Coordination, and Entry, 18 RAND J. Econ. 34 (1987); $c f$. M. Porter, Competitive Strategy 106 (1980) (advocating that oligopolists seek to establish an advantageous focal point through cheap talk).

39 The possibility of coordination is distinguished from the extent of coordination. If the policing problem is solved by the firms, coordination may still be imperfect and incomplete (as is likely when focal rules supply the terms of agreement). 
It might appear implausible that any particular outcome other than the competitive one could be identified with little or no interfirm communication in a complex industry setting, in which firms differ in costs and products, nonprice competition is extensive, and buyers differ in preferences. ${ }^{40}$ The problem of identifying terms of a coordinated understanding is actually simpler than it initially appears, however, because preexisting practices can often be taken as self-evident and, accordingly, can be grandfathered by the firms. This point may be clarified by distinguishing between focal rules and focal points.

In the typical oligopoly setting, many simply stated rules will each identify a set of related outcomes, with every outcome in such a set more preferred by all firms than competition. As the 1992 Horizontal Merger Guidelines recognize, "[f]irms coordinating their interactions need not reach complex terms concerning the allocation of the market output across firms or the level of the market prices but may, instead, follow simple terms such as a common price, fixed price differentials, stable market shares, or customer or territorial restrictions." 41 Such a rule freezes most preexisting firm practices. Once a focal rule of this sort is identified-for example, "preserve existing price differentials" or "preserve existing market shares"-identifying a focal point (a specific equilibrium outcome) turns merely on choosing a single parameter-such as the common percentage price increase or

$40 \quad$ E.g., Ginsburg, supra note 15.

$41 \quad 1992$ Merger Guidelines, supra note 16, at $\S 2.11$. Coordinating firms must agree on the terms of punishment as well as the terms of the high price outcome (the reward state). The focal rule for punishment might take the same form as the focal rule for the reward state. For example, firms might lower all prices by a common percentage should punishment be necessary, or raise output by a common percentage in order to preserve market shares. One punishment rule that is likely always to be potentially focal is a return to the competitive price and output (for some significant period of time). This punishment rule is also attractive because more severe punishments (such as below-cost pricing) may not be credible and because some more severe punishments may be prohibited by antitrust's bar on predatory conduct. For these reasons, most 
common percentage output reduction. ${ }^{42}$ In many industries, a particular focal rule will stand out as self-evident based on, for example, the information that firms routinely collect about their rivals. In general, focal rules can be expected to be simply stated and readily grasped. Outcomes consistent with the focal rule-the feasible set of coordinated outcomes-may fail to garner for the oligopolists much of the profit available from joint profit maximization (express collusion), but this is no bar to successful coordination because coordination need not be perfect or complete. ${ }^{43}$

The following hypothetical case suggests the way focal rules make it easy for oligopolists to reach the terms of a coordinated understanding. Consider a manufacturing industry in which each firm sells a number of products to retailers for later resale to consumers. Each firm might, for example, sell electrical equipment to hardware stores or candy to drug stores. The firms sell a number of products in the category (types of candy or electrical equipment) in multiple sizes and styles. Suppose that each firm in the industry publishes a price book, listing the prices it charges for all its products. Assume away the possibility that a manufacturer would be able to give a retailer a secret discount, ${ }^{44}$ and assume

examples in the text implicitly assume that the oligopoly will punish deviation merely by returning to competition.

42 The focal rules discussed in the text reduce the complexity of identifying terms of coordination to the choice of a single parameter. The argument would not be changed significantly if the focal rule were to reduce the coordination problem to the choice of a small number of parameters rather than a single parameter.

43 More technically, the feasible set of coordinated equilibria are those that are consistent with a plausible focal rule. This set need not contain the joint profit-maximizing equilibrium.

44 This assumption is made so that the example highlights the possibility of multiple equilibria and the significance of focal rules. Whether firms can quickly and reliably monitor the output and price decisions of their rivals is typically an empirical question. Hence, if a court is examining an actual industry of the sort being described, the ability of sellers to discount in secret may be an important issue in determining whether coordination is plausible. The ability of manufacturers to discount 
further that the prices set by any one manufacturer are immediately met by its rivals. Accordingly, excepting brief periods of transition, all price books are identical. These assumptions also imply that each firm can quickly and reliably monitor the prices and sales of its rivals, and that deviations would be punished immediately (as each firm lowers price to meet the price charged by the cheater).

These assumptions create an economic environment conducive to coordination. Rapid detection and response to deviation make cheating unlikely. Accordingly, any set of high prices simultaneously adopted by the firms will constitute an equilibrium outcome. Moreover, many such outcomes are possible; this industry presents a setting in which multiple equilibria are likely. The firms would accept many sets of prices (many price books) in preference to competition, should any of those price books be adopted by all, although at any instant only one set of prices is in fact the industry standard.

In this setting, coordination can be made more effective by making some other, higher set of prices focal. Complex changes in the price structure may be difficult to communicate, but it is easy to imagine one firm making a common percentage price increase focal by announcing that it has raised all prices in its previous price book by, say, five percent. All firms will recognize that if every rival follows immediately, the price increase will stick, but that if some rival does not follow, those that initially adopt the increase will return to the lower price. Moreover, within a large range of price changes, each firm will recognize that it is in its interest to match immediately. ${ }^{45}$ It is evident that multiple

secretly may be limited, for example, by the frequency of visits by manufacturers' sales representatives, the ability of those sales representatives to observe the shelf space and retail pricing of the products of rival manufacturers, and the existence of explicit or implicit "price protection" provisions (such as most favored nations or meeting competition clauses) in the supply agreements between manufacturers and retailers.

45 At some point, however, the announced price increase will generate a price so high as to shrink profits by shrinking demand, or so high as to make cheating more attractive to some firm than the alternative of 
outcomes are possible under these circumstances: the firms might equally raise all prices by four percent or six percent, or lower them by two percent.

In this example, the industry practice of adopting a price book establishes the focal rule of preserving existing price differentials. The choice of outcome within the set made feasible by this rule is reduced to the identification of a single, specific, common percentage price increase as a focal point. Despite the complexity of the industry setting, reaching the terms of coordination involves no more than the simple tasks of identifying first a focal rule, and then a focal point contingent on that rule.

The example can be used to illustrate the difference between coordination that is feasible without complex communication and what the firms would choose to do could they bargain to reach the joint profit-maximizing outcome. Some firms might prefer a higher common price increase than five percent and other firms might prefer less. For example, if the industry output reduction arising from a common increase in price falls largely on one particular firm, perhaps because products are differentiated and those buyers preferring its product are the most likely to do without in response to a small price rise, then that firm may prefer less of a price rise than does its rivals. Moreover, more complex patterns of price changes, such as raising price six percent on some products and three percent on others, might be more profitable for some or all of the firms than a common increase of five percent. Were the firms able to cooperate legally, they might in consequence bargain to a negotiated set of prices far different from preserving the existing price book differentials and raising all prices by five percent. ${ }^{46}$ These possibilities are not feasible, however, where antitrust law's

cooperation. Under such circumstances, one or more firms will balk at the price increase. As discussed in section IV below, mergers may enhance coordination may raising the lowest price at which a firm would prefer deviation to cooperation.

46 An express cartel would likely increase the market share of firms able to sell at the highest margin (e.g., because of low production costs), and compensate through side payments those rivals whose share would in consequence decline. 
prohibition of express and tacit agreements limits the terms of coordination to focal rules that are simply stated, thereby reducing the problem of identifying terms of coordination from a complex task to the choice of a single parameter. ${ }^{47}$

Even though the feasible set of coordination possibilities employing focal rules is smaller than the coordination possibilities available through express agreement, many feasible focal point outcomes are likely to be more profitable than competition for every firm in an oligopoly. And it is likely that the firms in an oligopoly will find a way to identify one such outcome. ${ }^{48}$ Under such circumstances, the difficulties of identifying terms of the

47 Bid-rigging may be easier to arrange than most other forms of express collusion because procurement specifications typically limit the dimensions of competition to one variable, price. Focal rules accomplish the same result of facilitating coordination by limiting the dimensions of competition to a small number of variables.

48 It is possible, though unlikely, that the firms will be unable to select among the multiple equilibria. As the 1992 Merger Guidelines recognize, if firms have "substantially incomplete information about the conditions and prospects of their rivals' businesses, perhaps because of important differences among their current business operations," they may find it difficult to bargain to a common understanding. 1992 Horizontal Merger Guidelines, supra note 16 , at $\$ 2.11$. Firms with a great deal of private information will have an incentive to take an extreme bargaining position and stick with it rather than compromise, knowing that their rivals cannot call their bluff. Under such circumstances, negotiations may break down altogether. If this bargaining problem would have affected express negotiations among the firms, had such negotiations taken place, it might also lead the firms to refuse to accept an equilibrium outcome that a rival is attempting to make focal. It is unlikely, however, that many industries will be unable to reach a coordinated understanding because of this problem. But cf. J. TIROLE, supra note 25 , at 242, 250-51 (cost asymmetries may make it difficult for firms to identify a focal equilibrium); supra at note $8 \&$ infra at note 117 (frequent, significant, and imminent entry, expansion, or innovation may impede reaching a coordinated understanding when the new competitor would prefer the competitive outcome to its profit under any focal coordination rule; such a firm may be so powerful a maverick as to inhibit coordination altogether). 
coordinated agreement will not impede coordination. ${ }^{49}$ Coordination is not inevitable because, as Stigler emphasized, successful oligopolists must also be able to monitor and punish deviation. But the contemporary economic insight that focal rules may provide the terms of agreement undercuts the significance of the concern that it may be difficult for oligopolists to negotiate the terms of their coordinated understanding.

II. The first dilemma: proving an agreement to fix price from circumstantial evidence

These developments in economics can be expected increasingly to lead a court considering whether to infer an agreement to fix price under Sherman Act $\S 1$ from parallel pricing and other circumstantial evidence of conspiracy to recognize a logical dilemma. The first horn of the dilemma is rooted in Stigler's insight that market structure affects the ability of firms to coordinate. If the economic environment in the industry in which parallel pricing is observed is not conducive to coordination, for example, because cheating is difficult to detect or punish, then it would be irrational for the firms to reach an agreement. If it would be irrational to agree, an agreement is unlikely to have been reached.

The second horn of the dilemma emerges from contemporary economic theory. If the economic environment is conducive to

49 Shifts in cost, demand, or market structure may induce the coordinating firms to renegotiate the terms of their arrangement by establishing a new focal outcome. Renegotiations of the coordinated understanding can be expected to occur often when such shocks are large and frequent, and when a new focal equilibrium can be established cheaply. See supra at note 38 and accompanying text (cheap talk facilitates the establishment of a focal equilibrium), supra at note 42 and accompanying text (renegotiation of a focal point may be facilitiated by preserving the focal rule), supra at note 48 (private information may impede renegotiation); $c f$. Slade, Cheating on Collusive Agreements, 8 INT'L J. INDus. ORG. 519 (1990) (unexpectedly high or low costs may induce deviation from a coordinated understanding). 
coordination, then the firms may establish focal rules for achieving high prices through coordination without engaging in the process that the law terms an agreement. Reaching an agreement may confer little additional market power upon the firms, and it will raise the risks of a costly antitrust prosecution. If an agreement is unnecessary for firms to achieve the observed coordinated outcome, then it would be irrational for the firms to agree; under such circumstances, parallel pricing will be understood as arising more plausibly from independent decision making under conditions of oligopolistic interdependence than from an agreement to fix price. Although the second horn of this dilemma does not apply unless industry behavior could be consistent with what would result were a coordinated understanding based on a plausible focal rule, the two horns of this dilemma can be expected to lead courts often to question whether it would be rational for the firms to agree. A court that experiences such doubts will be reluctant to infer an agreement to fix price under Sherman Act $\S 1$ from circumstantial evidence.

The argument of the first dilemma did not arise in the era before Stigler's pathbreaking analysis of oligopoly. The traditional legal approach to identifying an agreement from circumstantial evidence, established in mid-century, focused on detecting indicia of a secret conspiracy rather than on analyzing whether the economic environment was conducive to coordination. Stigler's picture of oligopoly, in conjunction with the increasing judicial focus on the economic rationality of alleged conspiracies, led antitrust to incorporate factors related to the economic plausibility of an agreement into the analytic methodology for identifying a $\S 1$ conspiracy, thereby allowing courts to recognize the first horn of the dilemma. If contemporary developments in economics have a similar power, the second horn of the dilemma will begin to flower judicially. With both horns of the dilemma in place, courts will become significantly more reluctant to infer a horizontal agreement to fix price under Sherman Act $\S 1$ from circumstantial evidence than were their predecessors at mid-century. 
A. Traditional legal doctrine, mere oligopolistic interdependence, and conscious parallelism

The idea of an agreement among competitors was clarified in a debate around the middle of the 20th century over whether a $\$ 1$ agreement could be inferred from the simultaneous increase in prices by the handful of rivals in an oligopoly-that is, from conduct termed "conscious parallelism." The debate was framed around answering a simple question: With nothing more in the evidentiary record than parallel price increases and an oligopoly setting, should a § 1 agreement to restrain prices be inferred?

During the era in which the structural school dominated antitrust commentary, the primary argument for inferring a horizontal agreement on price from evidence limited to parallel price increases among firms recognizing their interdependence was that oligopolistic interdependence was thought likely to lead to high prices similar to those that would be charged had the firms created a "trust" (cartel) of the sort that existed before $\$ 1$ was enacted. If express collusion is unlawful, it would seem that parallel pricing in an oligopoly, a practice resulting in a similar harm, should also be deemed to violate Sherman Act $§ 1$.

This argument for deeming parallel pricing among oligopolists a violation of $\S 1$ was ultimately rejected by the antitrust mainstream, for the reasons set forth in Donald Turner's influential 1962 article on conscious parallelism. ${ }^{50}$ The key economic insight underlying the reluctance to reach conscious parallelism under the Sherman Act was the recognition that parallel pricing is typically unavoidable in an oligopoly. Whether they are competing or cooperating, oligopolists will be led to charge the identical price. ${ }^{51}$

so Turner, The Definition of Agreement Under the Sherman Act: Conscious Parallelism and Refusals to Deal, 75 Harv. L. REv. 655 (1962). These issues had been debated prior to Turner's article. E.g., THE Attorney General's National Commtttee to Study the AnttrRust Laws, REPORT 36-42, 327, 331-32 (S. Barnes \& C. Oppenheim eds. 1955).

s1 If firm products differ in quality, prices will be led to be identical after adjusting for the differences in quality perceived by the marginal buyer. Under such circumstances, parallel pricing will take the form of 
Any firm charging a price higher than that of its rivals (for longer than a brief period) will be forced to reduce that price because it will lose too many sales. Any firm charging a price lower than that of its rivals will find that its rivals will rapidly lower price to match. Accordingly, all firms will be led to change price simultaneously and identically, regardless of whether the price changes have an innocent explanation (e.g., a response to variation in industry demand or costs) or whether prices rise as a result of a cooperative effort to exercise market power.

Because conscious parallelism is unavoidable in an oligopoly, a court that found an agreement among competitors to fix price solely from evidence of a parallel increase in price in a concentrated industry would find it difficult to frame satisfactory relief.52 An injunction barring conscious parallelism is problematic because a court would have nothing to enjoin; it is not practical to forbid conduct that is unavoidable. Nor would it be practical for a judge to issue an injunction barring above-cost pricing. Cost is difficult to determine, ${ }^{53}$ and a court will properly be reluctant to

simultaneous changes in price that preserve a constant differential. See United States v. Socony-Vacuum Oil Co., 310 U.S. 150, 222 (1940).

52 Richard Posner terms this the "decisive" objection raised by Turner. Posner, supra note 7, at 1564.

53 Accounting measures of cost often differ significantly from the underlying economic concept, in ways difficult to unravel, because of the accounting allocation of costs across products and over time (depreciation). For example, it is often difficult to distinguish from accounting data rents from investments in advertising or new product design from economic profits. For this reason, academic economists attempting to identify market power empirically increasingly treat cost as unobservable. See Bresnahan, Empirical Studies of Industries with Market Power, in HandBook of Industrial Organization 1011-57 (R. Schmalensee \& R. Willig eds. 1989). Courts similarly find it challenging to determine cost from accounting data when evaluating claims predicated upon below-cost pricing. See ABA Antrtrust Section, ANTtrRust Law DevelOPMENTS 227-34 (3d ed. 1992). Moreover, a cost-based standard for prices would be difficult to apply because the appropriate measure of cost to be compared with price is not always obvious. Price would equal marginal cost in the competitive (free entry) equilibrium, unless marginal cost pricing would produce insufficient contribution to profit to cover a 
enjoin prices in excess of costs for fear that it will be forced into ongoing regulatory supervision of the defendants. ${ }^{54}$

If antitrust law were to permit a court to deem mere parallel pricing in an oligopoly setting to violate $\S 1$, moreover, that result would blur the existing line between unilateral and concerted behavior. Indeed, if conscious parallelism is frequently unavoidable among oligopolists in concentrated industries, it is hard to see how an oligopolist acting innocently, with no intent to agree, could avoid being held liable. A criminal prosecution for a horizontal restraint on price under such circumstances would appear to conflict with the criminal law's requirement of mens rea. ${ }^{55}$ For all these reasons, antitrust law does not permit the inference of a horizontal agreement to fix price from evidence limited to parallel pricing in a concentrated industry. ${ }^{56}$ In the words of the Supreme

normal economic return on capital. The latter situation may arise when fixed costs are large or marginal cost decreases with output. Then the competitive price would equal an entrant's marginal cost (which might often be approximated by incumbent average cost).

54 Whenever costs increase, defendants can be expected to petition for modification of the relief to allow higher prices. And whenever costs decrease, customers will seek modification to require lower prices.

55 The state of mind required for criminal culpability may be demonstrated even if defendant had no desire to conspire, but merely an intention to match the price charged by its rivals, through proof that defendant knew that the consequences of raising price would be to violate the law. See United States v. United States Gypsum Co., 438 U.S. 422, 443-46 (1978). Thus, if conscious parallelism is deemed an agreement in violation of the Sherman Act, the requisite mental state could arguably be inferred from the parallel behavior even in the absence of specific intent to agree.

56 As these overwhelming difficulties of using Sherman Act $\S 1$ to address the oligopoly problem became clear, other approaches to that end were debated. In other writings, Turner proposed interpreting the monopolization prohibitions of Sherman Act $\$ 2$ to reach beyond monopolies to oligopolies, and he proposed dissolving large firms in concentrated industries (regardless of whether the oligopolists were actually cooperating). Turner, The Scope of Antitrust and Other Economic Regulatory Policies, 82 HARv. L. Rev, 1207, 1231 (1969); C. KAysen \& D. TURNer, ANTITRUst Policy 110-19, 266-72 (1959). Critics charged that these poli- 
Court, " 'conscious parallelism' has not yet read conspiracy out of the Sherman Act entirely." 57

The courts responded to the objections to inferring a horizontal agreement solely from evidence of parallel pricing by creating the legal rule of "parallelism plus," under which circumstantial evidence of a horizontal agreement remains tested today. ${ }^{58}$ Under this rule, an agreement to fix price cannot be inferred from paral-

cies would penalize firms for exploiting scale economies in production and that they would encourage large firms to charge very high prices in order to limit their own market share by preserving high-cost fringe suppliers in the marketplace. For these reasons, antitrust never broadened the scope of $\$ 2$ to apply to oligopolies, but $c f$. United States v. American Airlines, Inc., 743 F.2d 1114 (5th Cir. 1984) (attempted monopolization found when one firm expressly solicited a price increase from its only rival), cert. dismissed, 474 U.S. 1001 (1985), and "no-fault" demonopolization legislation was never enacted, Kovacic, Failed Expectations: The Troubled Past and Uncertain Future of the Sherman Act as a Tool for Deconcentration, 74 Iowa L. REv. 1105, 1126-27 (1989). The debate over these proposals ended when the Chicago approach became antitrust's mainstream. Turner also attempted to impede the creation of oligopolistic market structures through strict antitrust review of mergers, as reflected in the Justice Department's 1968 Merger Guidelines, which were promulgated while Turner was the Assistant Attomey General for Antitrust.

57 Theatre Enters., Inc. v. Paramount Film Distrib. Corp., 346 U.S. 537, 541 (1954).

586 P. AReEda, ANTitrust Law 1434a (1986). Absent evidence beyond parallel pricing, as would be provided by "plus factors," a fact finder cannot reject the view that firms have acted unilaterally in favor of the view that the firms have cooperated, even in settings where the firms are sufficiently few as to recognize their interdependence. Indeed, a court cannot consider whether an agreement exists from evidence of parallel pricing alone, because that evidence does not make the inference of price fixing more plausible than the inference of (legal) independent decision making. Matsushita Elec. Indus. Co. v. Zenith Radio Corp., 475 U.S. 574 (1986); Monsanto Co. v. Spray-Rite Serv. Corp., 465 U.S. 752 (1984). Accordingly, evidence of parallel conduct without plus factors is insufficient as a matter of law to meet the civil burden of proof for finding a conspiracy. 
lel pricing in the absence of other circumstantial evidence, the socalled plus factors. 59

The plus factors that have been the most prominently relied upon by courts reflect the central concern of the leading Supreme Court decisions from mid-century on inferring an agreement from circumstantial evidence: ${ }^{60}$ to discover and uproot trusts pushed underground by the Sherman Act. ${ }^{11}$ When these plus factors are

59 The fact finder's task in identifying an agreement requires more than counting the number of plus factors on some checklist; the evidence bearing on the inference of conspiracy is taken as a whole. Moreover, the acts giving rise to the inference of an agreement (the plus factors) may in themselves be wholly innocent. American Tobacco Co. v. United States, 328 U.S. 781, 809 (1946).

60 The leading cases include Interstate Circuit, Inc. v. United States, 306 U.S. 208 (1939); United States v. Socony-Vacuum Oil Co., 310 U.S. 150 (1940); Theatre Enters., Inc. v. Paramount Film Distrib. Corp., 346 U.S. 537 (1954); see American Tobacco Co. v. United States, 328 U.S. 781 (1946) (Sherman § 2 conspiracy). Cf. R. PosNER, supra note 7, at 24-26 (arguing that in 1940, the Supreme Court established a rule of law that focused solely on evidence of conspiracy, ignoring evidence of the economic effect of the challenged conduct). The goal of uprooting secret conspiracies also affected the formulation of antitrust's per se rule against horizontal price fixing. If a hidden agreement could be identified, liability followed without an inquiry into the economic effect of the agreement or the reasonableness of the prices charged. Why, after all, would the parties reach a secret agreement unless they were up to no good? See United States v. Socony-Vacuum Oil Co., 310 U.S. 150, 224 n.59 (1940). This per se rule has partially eroded since 1979, as indicated supra at note 2. Historically, a second line of Sherman Act $\$ 1$ decisions examined whether openly acknowledged agreements were reasonable. E.g., United States v. Container Corp. of America, 393 U.S. 333 (1969); Sugar Inst. v. United States, 297 U.S. 553 (1936); Maple Flooring Mfrs. Ass'n v. United States, 268 U.S. 563 (1925); American Column \& Lumber Co. v. United States, 257 U.S. 377 (1921); Chicago Bd. of Trade v. United States, 246 U.S. 231 (1918).

61 Prosecutors and courts legitimately feared that secret conspiracies were commonplace in big business, especially after the shocking revelation in 1960 that executives of General Electric and Westinghouse had participated in a criminal price-fixing conspiracy involving electrical equipment. E.g., J. Fuller, The Gentleman Conspirators: The Story of Price Fixers IN the Electrical Industry 218 (1962) (price fixing is 
observed in conjunction with parallel pricing, they suggest a secret agreement on price. They include: 62

a. proof that the rivals had the opportunity for direct communication, ${ }^{63}$ or that they in fact communicated directly; ${ }^{64}$

b. evidence of anticompetitive intent behind the parallel conduct; 65

"simple and easy to do; extremely difficult to detect and prove"); J. HERling, The Great PRice Conspiracy: The Story of the ANTtTrust ViolaTIONS IN THE ELECTRICAL INDUSTRY 304 (1962) (the indictment "revealed the hitherto secret premises of economic decision for a significant section of the economy"). While it is possible that the focus on hidden cartel agreements was encouraged by the Cold War fear of secret conspiracies at home and abroad, the continuing active criminal price-fixing enforcement program of the Justice Department suggests that attention to price fixing cannot be dismissed as an anachronism.

62 Other plus factors, related to the plausibility of an agreement in the economic environment of the industry at issue rather than to the desire to uproot a hidden cartel, are discussed infra at notes 77-79 and accompanying text.

63 Pittsburgh Plate Glass Co. v. United States, 260 F.2d 397, 400-01 (4th Cir. 1958) (agreement inferred when simultaneous price increase follows meeting among competitors at which higher prices were discussed), aff $d$ on other grounds, 360 U.S. 395 (1959).

64 Apex Oil Co. v. DiMauro, 822 F.2d 246, 255 (2d Cir.), cert. denied, 484 U.S. 977 (1987); United States v. Champion Int'l Corp., 557 F.2d 1270 (9th Cir.), cert. denied, 434 U.S. 938 (1977); United States v. Foley, 598 F.2d 1323, 1332 (4th Cir. 1979), cert. denied, 444 U.S. 1043 (1980); see Interstate Circuit, Inc. v. United States, 306 U.S. 208 (1939) (agreement found when the proposed course of conduct was communicated to rivals as well as customers, then adopted by the industry with minor modifications). The secrecy of discussions among competitors (e.g., secret meetings) may count in favor of finding an agreement when it suggests guilty knowledge on the part of the conspirators. 6 P. AREEDA, supra note 58, at $\$ 1417 \mathrm{~d}$. Moreover, personal meetings of conspirators are more dangerous to competition than information exchanged publicly (e.g., through the press) to the extent meetings permit more complex exchanges of information. See id. at $\llbracket 1435 \mathrm{~b}$ (private meetings), $\llbracket 1435 \mathrm{c}$ (public communication).

65 E.g., In re Coordinated Pretrial Proceedings in Petroleum Prods. Antitrust Litig., 906 F.2d 432, 446 (9th Cir. 1990), cert. denied, 111 S. Ct. 2274 (1991). 
c. behavior difficult to imagine as arising in the absence of detailed communication, because it appears arbitrary or unusually complex; ${ }^{56}$ or

d. behavior difficult to understand as rational in the absence of an agreement, ${ }^{67}$ including the absence of a legitimate justification for the practice. ${ }^{68}$

66 The theory of conscious parallelism has been said to justify a finding of conspiracy when the parallelism is of an "elaborate and complex nature" along with "a web of circumstantial evidence pointing very convincingly to the ultimate fact of agreement." Delaware Valley Marine Supply Co. v. American Tobacco Co., 297 F.2d 199, 206 n.19 (3d Cir. 1961), cert. denied, 369 U.S. 839 (1962). Compare In re Coordinated Pretrial Proceedings in Petroleum Prods. Antitrust Litigation, 906 F.2d 432, 449 (9th Cir. 1990) (finding agreement when posted information was "unusually detailed"), cert. denied, 111 S. Ct. 2274 (1991) with Wilcox v. First Interstate Bank, 815 F.2d 522 (9th Cir. 1987) (no agreement found when the only information announced was the prime lending rate).

67 Interstate Circuit, 306 U.S. at 223 (It "taxes credulity" to imagine that the conduct would have occurred absent "some understanding that all were to join"); American Tobacco, 328 U.S. at 805 (prices rose when costs declined); Morton Salt Co. v. United States, 235 F.2d 573, 578 (10th Cir. 1956) (upholding price-fixing conviction when conspirator who cut off discounting distributor from access to low-priced product for resale was "acting against its economic interest"). The idea of actions not rational but for an agreement raises troublesome analytic difficulties in application, see Yao \& DeSanti, supra note 7, at text accompanying notes $39-47$, that are closely related to the problems of applying the definition of an agreement, discussed infra at notes 69-71 and accompanying text.

68 E.g., Ambook Enters. v. Time Inc., 612 F.2d 604, 615 (2d Cir. 1979), cert. dismissed, 448 U.S. 914 (1980). While the presence of a legitimate business justification-also termed an efficiency explanation in the contemporary economic language of antitrust-need not defeat the inference of an agreement from other evidence, a weak, pretextual, or nonexistent justification encourages such an inference. (The presence of a business justification for firm behavior also enters into the Sherman $\S 1$ analysis in two ways beyond its role as a factor relevant to determining whether the behavior constitutes an agreement: as a factor relevant to determining whether an agreement should be characterized as illegal per se, and as a factor relevant to determining whether an agreement is unreasonable if the behavior is analyzed under the rule of reason.) 
In this way, antitrust law employed plus factors to operationalize the legal concept of an agreement. This strategy for determining whether to infer an agreement from circumstantial evidence was more attractive than the alternative of applying to the facts of each case a definition of the term "agreement," because the most common definitions would appear to require a court to infer a horizontal conspiracy from mere parallel pricing. For example, if an agreement is defined as a meeting of the minds, ${ }^{69}$ a court conscientiously applying the definition would likely infer an agreement from the consciously parallel interaction among oligopolists. ${ }^{70}$ When firm 1 raises price, expecting firm 2 to do the same, and firm 2 rises price expecting firm 1 to likewise, the firms have reached a common understanding by communicating solely through their pricing actions. ${ }^{71}$

69 A § 1 agreement is said to mean a "common design and understanding, or a meeting of minds in an unlawful arrangement," American Tobacco Co. v. United States, 328 U.S. 781, 810 (1946), "mutual consent," Esco Corp. v. United States, 340 F.2d 1000, 1007-08 (9th Cir. 1965), or "a conscious commitment to a common scheme," Monsanto v. Spray-Rite Serv. Corp., 465 U.S. 752, 768 (1984).

70 Posner, supra note 7, at 1576.

71 The following objection might be offered to the above application of the definition of an agreement. Consider two firms that price competitively, at cost. If firm 1 observes its costs have increased, and if it recognizes that firm 2's costs have increased, then firm 1 will raise price by the amount of the cost increase in the expectation that firm 2 will be forced to do likewise. Similarly, firm 2 will raise price expecting firm 1 to go along. By the meeting of the minds definition, this conduct would seem to constitute an agreement. Yet antitrust law should not reach this conduct, because the behavior is competitive: the firms price at cost, and prices merely respond to shifts in cost. As a general critique of the use of the definition for identifying an agreement, this objection is unsatisfactory, however, because a meeting of the minds is unnecessary for competitive firms to find it rational to change prices when costs change. Firms pricing at marginal cost will be forced to raise price when their costs increase regardless of what their rivals do. This rejoinder in effect exempts one set of prices, those based on cost, from the set of oligopoly equilibrium outcomes from which a meeting of the minds would be found. 
By operationalizing the idea of an agreement, antitrust law clarified that the idea of an agreement describes a process that firms engage in, not merely the outcome that they reach. ${ }^{72}$ Not every parallel pricing outcome constitutes an agreement because not every such outcome was reached through the process to which the law objects: a negotiation that concludes when the firms convey mutual assurances that the understanding they reached will be carried out. ${ }^{73}$ The plus factors suggestive of a secret agreement permit the inference that the parallel pricing resulted from firms interacting in the forbidden manner. By raising the costs of reaching complex bargains, antitrust law hopes to reduce the prevalence of such bargains. ${ }^{74}$

72 The distinction between process and outcome implicit in antitrust law's preference for identifying agreements through plus factors rather than by applying a definition of an agreement has no strong parallel in contract law, because, unlike antitrust litigation, contract litigation rarely if ever involves an attempt by prosecutors or third-party victims to demonstrate an agreement denied by the parties alleged to have reached it. Nevertheless, contract law incorporates doctrines that can be interpreted as insisting that the parties engage in negotiations and convey mutual assurances before an agreement will be found. For example, when contract law refuses to find a contract in cases of mutual or unilateral mistake, it recognizes that identifying a contract involves more than a determination that the parties have settled on a specific text (outcome); finding an agreement also turns on a determination that the process of reaching that outcome is consistent with that process which contract law contemplates.

73 See 6 P. AREEDA, supra note 58, at $\$ 1404$ (an agreement involves "collective decision-making plus mutual assurance of compliance," although, as an evidentiary matter, "either element alone may suffice to establish an antitrust agreement"), I 1410c (unlawful agreement distinguished from lawful interdependence by "some level of commitment to a common course of action"). Although mere assurances are unlikely to be credible commitments to carrying out the collective understanding, $c f$. text supra, at notes 25-26 (punishment threats are empty unless accompanied by commitments), they may nevertheless facilitate coordination by helping firms establish an equilibrium outcome as focal.

74 Economics has only one theory of the way firms reach equilibria: if there is only one equilibrium, firms go there, and if there are multiple 
The traditional antitrust analysis of an agreement that matured in the middle of the 20th century was well suited to the detection of secret horizontal conspiracies among oligopolists. With evidence of parallel pricing augmented by indicia that the firms had negotiated an understanding and provided each other with mutual assurances that their deal would be carried out, a court was permitted to infer that a horizontal agreement had been reached. The legal doctrine of parallelism plus encouraged judicial vigilance against the threat of hidden agreements among oligopolists. Courts had broad scope to infer agreements from circumstantial evidence, excepting when the evidence consisted solely of parallel pricing. The logical dilemma that is the subject of this section had not begun to flower.

\section{B. The influence of Stigler's picture of oligopoly}

As antitrust began to recognize the significance of Stigler's economic insights for understanding the interaction among oligopolists, the logic of the first horn of the first dilemma began to emerge. Stigler provided a theory by which courts could distinguish industries in which cooperation is plausible from industries not susceptible to cooperation. As the courts grew to recognize this possibility, they began to employ additional plus factors in $\S 1$ analysis to guarantee that the industry environment at issue is fertile ground for cooperation..$^{75}$ These economic plausibility plus factors include: ${ }^{76}$

equilibria, firms identify one (e.g., one that is focal) and then go there. The economic logic for prohibiting the particular mechanism for equilibrium selection objected to by the law is that the conduct termed an agreement lowers the transactions cost of identifying those coordinated equilibria that cannot be made self-evident through the establishment of a simple focal rule.

75 Although these factors can be thought of as merely elaborating the previously noted plus factor that the conduct be difficult to understand in the absence of an agreement, see supra at note 65 and accompanying text, separating them in this fashion highlights the influence of economic developments on antitrust doctrine. 
a. a market structure conducive to cooperation (including ease of reaching the terms of agreement, and of detecting and punishing deviation from those terms); ${ }^{77}$

76 In addition to the factors highlighted in the text, Posner in effect suggests that direct evidence of the exercise of market power by an industry, such as evidence of price discrimination or prices in excess of costs, should count as a plus factor permitting a court to infer an agreement from parallel pricing in an oligopoly setting. Posner, supra note 7 , at 1578-83. Such evidence, if believed, would conclusively demonstrate that the exercise of market power was possible. Antitrust enforcers experimented unsuccessfully with this suggestion in the 1970s. The Federal Trade Commission's efforts to prove monopoly power foundered on the difficulty of identifying cost, a problem highlighted, but perhaps underestimated, by Posner. See Elzinga, Unmasking Monopoly: Four Types of Evidence, in ECONOMICS AND ANTITRUST Policy 11-38 (R. Larner \& J. Meehan eds. 1989). The recent development of econometric techniques for measuring market power that treat cost as an unobservable offer the possibility that antitrust might now be able practically to adopt Posner's suggestion. See generally, Baker \& Bresnahan, Empirical Methods of Identifying and Measuring Market Power, 61 ANTITRust L.J. 3 (1992).

77 See Montana v. SuperAmerica, Inc., 559 F. Supp. 298 (D. Mont. 1983) (no concerted action to set prices in retail gasoline market, despite parallel pricing and price posting); $c f$. Ginsburg, supra note 15 (extensive nonprice product dimensions may make coordination implausible). A market's structure is also not conducive to coordination if an anticompetitive price rise would be defeated by new competition or deterred by the prospect of new competition. Cf. E.I. du Pont de Nemours \& Co. v. F.T.C., 729 F.2d 128, 131 (2d Cir. 1984) (Ethyl) (analyzing likelihood of entry in evaluating a challenge under FTC Act $\S 5$ to unilateral practices alleged to facilitate coordination). For this reason, entry plays a major role in the analysis of whether mergers are likely to lessen competition by facilitating coordination. Ordover \& Baker, Entry Analysis Under the 1992 Horizontal Merger Guidelines, 61 AnTrTrust L.J. 139 (1992). Moreover, if the alleged conspirators are distant rivals, for example because the products they sell are so highly differentiated as to make each firm care little about the price and output decisions of the others, the firms may have little to gain from coordination. Such a market would not be congenial to coordination. 
b. evidence of coercion of potential cheaters; ${ }^{78}$ or

c. a history of express collusion among the defendants. ${ }^{79}$

Given the powerful influence of Stigler's economic approach to cooperation in merger analysis, ${ }^{80}$ and the pervasive influence of economic analysis throughout antitrust since the mid-1970s, it is not surprising that economic plausibility plus factors have played

78 E.g., Ambook Enters., 612 F.2d at 616; Penne v. Greater Minneapolis Bd. of Realtors, 604 F.2d 1143, 1148-49 (8th Cir. 1979). For such conduct to be considered coercive, the court must presumably have some basis for distinguishing the possibility that the coercing firm was merely meeting competition. Cf. 6 P. AREEDA, supra note 58, at $11408 \mathrm{~b} 2$ (evaluating fairness to the coercing firm when finding a coerced conspiracy).

79 See Proposed Modification of Existing Judgments, U.S. v. General Electric, 42 Fed. Reg. 17,004 (1977). Express collusion in related settings, for example among firms in the same industry but in different geographic markets, or among the same firms in some other market, would also suggest that the economic environment is conducive to collusion to the extent the industry structure in the related market is similar to that of the market at issue. See generally, 6 P. AREEDA, supra note 58, at I 1421.

80 An analysis of the economic plausibility of cooperation has become a staple of merger review at the federal enforcement agencies and, increasingly, the focus as well of judicial review of proposed acquisitions. Beginning with the promulgation of the 1982 Merger Guidelines, the Justice Department's investigation of mergers has incorporated "other factors" (beyond concentration and entry), reflecting the ability of firms to monitor and police an agreement, into the analysis of the likelihood that a merger will cause a competitive industry to cooperate. 1982 Department of Justice Merger Guidelines, 4 Trade Reg. Rep. (CCH) \13,102 § III.C; cf. Posner, supra note 7, at 1603-04 (recommending a similar approach to merger analysis). These factors remain part of the coordinated competitive effects analysis in the 1992 Merger Guidelines, supra note 16 , at $\S \S 2.11,2.12$. In the courts, Stigler's influence on merger analysis is apparent in the increasing sympathy of judges toward the defense that the specific industry at issue is not susceptible to cooperation because of the presence of a large or sophisticated buyer, which deters coordination through its ability to induce a seller to deviate. See generally, Pratt, The "Sophisticated Buyer" Defense in Merger Litigation Gains Momentum, 6 ANTITRUst 9 (Spring 1992). 
an increasingly significant role in identifying an agreement from circumstantial evidence in parallel conduct cases. ${ }^{81}$ But the secret agreement plus factors have remained primary; courts writing since Stigler's 1964 article have ignored the economic plausibility factors as much as they have employed them.

The limited role for the economic plausibility plus factors in the immediate wake of Stigler's article is suggested by an appellate opinion from 1979, written after Stigler's landmark article but before the judicial success of the Chicago revolution was assured. In the 1979 decision, the Fourth Circuit upheld the criminal conviction of nine real estate brokers in a Maryland county under Sherman Act $\S 1.82$ The brokers were found to have agreed to raise their commission rate on listed houses from six percent to seven percent. The evidence for an agreement was entirely circumstantial. ${ }^{83}$ The court noted, inter alia, that one broker raised the rate reported in the local multiple listing service to seven percent in response to an anonymous complaint that it had accepted a six percent listing, while secretly rebating one percent to the seller. This fact was treated as favoring the inference of an agreement, on the ground that it showed the defendant's intention to agree

81 However, some antitrust prosecutors contend that evidence about the economic plausibility of an agreement is more likely to be confusing than probative to the fact finder, especially when a conspiracy can be established through direct evidence. See generally, Gorey, Jr. \& Einhorn, The Use and Misuse of Economic Evidence in Horizontal Price-Fixing Cases, 12 J. CONTEMP. L. 1 (1986).

82 United States v. Foley, 598 F.2d 1323 (4th Cir. 1979), cert. denied, 444 U.S. 1043 (1980).

83 At a dinner meeting of leading realtors, one broker announced a plan to raise commission rates. In the ensuing discussion, the competing firms gave the impression that they would follow. The first broker in fact raised commission rates, and over the next few months, its rivals raised rates as well. All the firms knew that collective action was necessary for a rate increase to be successful, because the other firms had not gone along when one broker had previously raised rates unilaterally. Some firms also complained to those rivals who continued to accept some listing at the old commission rate. 
and that it demonstrated that intention to the co-conspirators. A court more heavily influenced by Stigler, in contrast, would have acknowledged that this fact also cuts against the inference of agreement, by demonstrating the ease by which the alleged conspirators could cheat secretly. ${ }^{84}$ Although the decision of the circuit court to uphold the finding of conspiracy was not remarkable on the facts of the case taken as a whole, a court more strongly influenced by Stigler would likely have noted this difficulty with that conclusion. ${ }^{85}$

The economic plausibility plus factors likely count for more today than they did in 1979, however, because the Supreme Court, in a 1986 decision, arguably mandated an economic analysis in civil antitrust conspiracy litigation. In that year, the Supreme Court decision upheld the award of summary judgment to defendants in a horizontal conspiracy case on the ground that plaintiffs'

84 The same court that ignored the implications of Stigler's article in deciding a conspiracy case might nevertheless have given greater attention to the economic evidence concerning the ability of firms to detect and punish deviation had two large real estate brokers in another county sought to merge. In the merger context, an argument about the economic plausibility of coordination would have likely possessed greater force after 1982, however, when the Justice Department revised its merger guidelines to incorporate economic insights derived from Stigler.

85 Even a court that undertakes an economic analysis of the plausibility of collusion can miss some potentially important points. In 1983, for example, a district court agreed with the owner of two gasoline service stations, charged as a conspirator in a price-fixing case, that the defendant was not a party to the conspiracy. Montana v. SuperAmerica, Inc., 559 F. Supp. 298 (D. Mont. 1983). The court refused to find that the defendant agreed to fix prices on the ground that its price changes could not be distinguished from unilateral, independent decision making. In reaching this conclusion, the court relied on its conclusion that the market structure was not conducive to collusion, and on the absence of a showing that the defendant engaged in "cartel enforcement actions." Although this decision was likely correct, the court failed to note that the ability of gas stations to monitor rival pricing actions quickly and cheaply facilitates coordination, and thus weighs against its conclusion that the economic environment was not hospitable to collusion. 
claim made "no economic sense." 86 In consequence, the lower courts will likely now be led to give greater attention to the economic plausibility plus factors than they did in the first two decades following Stigler's article. ${ }^{87}$

With the increasing importance of the economic plausibility plus factors, the first horn of the first dilemma emerges. If an industry structure conducive to coordination counts as a plus factor tending to make the inference of an agreement more plausible, it requires but a small additional reasoning step to conclude that it makes "no economic sense" to infer an agreement when the industry structure is not conducive to coordination. Courts are already comfortable with similar reasoning in the context of merger analysis, where they seek to determine whether a change in market structure will lessen competition. ${ }^{88}$ Accordingly, the analytic stage has been set for courts to conclude that in an industry with an environment not conducive to coordination, an agreement among competitors to fix price is not plausible and should

86 Matsushita Elec. Indus. Co. v. Zenith Radio Corp., 475 U.S. 574, 587, 596, 597-98 (1986). Accord, Eastman Kodak Co. v. Image Technical Servs., Inc., 504 U.S. _ 112 S. Ct. 2072, 2083 (1992) ("If the plaintiff's theory is economically senseless, no reasonable jury could find in its favor and summary judgment should be granted").

$87 C f$. ABA Antitrust Section, supra note 53, at 8 (arguing that since Matsushita, courts have increasingly held that the mere opportunity to conspire, a secret agreement plus factor, is insufficient to support an inference of conspiracy where the communication has a plausible legitimate business justification); DeSanti \& Kovacic, Matsushita: Its Construction and Application by the Lower Courts, 59 ANTTTRUst L.J. 609, 640-41 (1991) (some lower courts applying Matsushita have assessed the economic merits of claims).

88 There need be no logical inconsistency if courts are systematically willing to find criminal price fixing in the same markets in which they would refuse to find concentrating mergers anticompetitive, however, because merger analysis is prospective and probabilistic, while a pricefixing prosecution is retrospective. 
not be inferred from circumstantial evidence. ${ }^{89}$ This reasoning engages the first horn of the first dilemma.

\section{The emerging influence of contemporary developments in economics}

The second horn of the first dilemma emerges from contemporary developments in economics. In an industry in which firms would readily detect and police deviations from a coordinated arrangement, so that coordination is likely if a coordinated understanding can be reached, focal rules may provide the necessary terms of the understanding. Hence, if the observed outcome is consistent with a plausible focal rule, it is unlikely that the firms reached it through the bargaining process that constitutes an agreement under antitrust law. It would be irrational for the firms in such an industry to agree, because they could reach a coordinated outcome without risking antitrust liability merely by making that outcome focal. Again, an agreement would make "no economic sense."

This logic can be illustrated in the context of the hypothetical example, discussed above, of coordination in the candy or electrical equipment industry. In the example, the focal rule for coordination involves preserving the relative price differentials in the existing price book. The example assumes that the firms have

89 Evidence of the economic implausibility of coordination is unlikely to be strongly probative toward proving that an unlawful conspiracy does not exist, however, when the record includes otherwise uncontroverted direct evidence of an agreement. This situation could arise, for example, if the firms have misperceived the ex ante likelihood that a collusive agreement could be maintained. Similarly, it is possible to imagine a court inferring an agreement from strong circumstantial evidence despite an economic environment uncongenial to coordination. Indeed, in an appropriate case, evidence concerning the economic plausibility of coordination may be excluded as confusing or prejudicial under Fed. R. Evid. 403. See generally, Gorey, Jr. \& Einhorn, supra note 81. Moreover, even when the firms correctly perceive their environment, it will not always be easy for a court to classify an industry as conducive to coordination or not. 
developed a method of deterring secret discounts by monitoring and policing deviation, so that the only remaining coordination problem is the identification of the terms of agreement. Under such circumstances, mere price leadership-one firm announcing that it is increasing prices by five percent-would be sufficient for the firm to identify the terms of a coordinated arrangement by making them focal, and thereby solve the remaining coordination difficulty. Even if the other firms follow by matching the five percent price rise, no agreement will be found under Sherman Act § 1 even though the industry environment is, by assumption, conducive to coordination. With no additional plus factors, the observed behavior would be deemed mere parallel conduct. As emphasized in a recent opinion of the First Circuit, "[o]ne does not need an agreement to bring about . . . [a] follow-the-leader effect in a concentrated industry." 90

Suppose that the facts now change slightly. One firm announces it has raised all prices in its price book by five percent, effective immediately. Some other firm calls a press conference the next week to announce it is raising prices only three percent, effective immediately. The remaining firms publish new price books with a three percent price rise the next day, and the firm that initially announced a five percent price rise also issues a new price book the next day, now lowering its price increase to three percent. Assume further that costs and demand do not change before or during the price jockeying.

Applying the plus factors, this conduct might be found to constitute an agreement under Sherman Act $\S 1$. As with any case of parallel pricing in an oligopoly setting, the facts are consistent with the idea that the firms are negotiating the terms of their bargain. From this perspective, the second firm vastly preferred the

90 Clamp-All Corp. v. Cast Iron Soil Pipe Inst., 851 F.2d 478, 484 (1st Cir. 1988), cert. denied, 488 U.S. 1007 (1989); accord, Reserve Supply Corp. v. Owens-Corning Fiberglas Corp., 1992-1 Trade Cas. (CCH) I 69,913 at 68,370 (7th Cir. 1992); cf. 6 P. AREEDA, supra note 58, at I 1435h ("once a pricing formula comes into existence, each firm may choose to use it solely through interdependent calculation"). 
three percent price increase to a five percent increase, ${ }^{91}$ so much so that it attempted, successfully, to make three percent the focal point rather than five percent. Thus, a court focusing on the plus factors that convert parallel pricing into an unlawful agreement to fix price might interpret the first firm's price announcement and the second firm's press conference as communication. Moreover, the assumptions that costs have not risen and demand did not grow more inelastic might help supply another plus factor favoring the inference of an agreement, if a court concludes from that fact that the common three percent price rise has no legitimate business justification. ${ }^{92}$ Finally, a court could recognize a third plus factor, that the market structure is conducive to coordination,

91 The second firm might bear a disproportionately high share of the reduction in industry demand associated with a price rise greater than three percent, or the second firm might have cheated had the five percent price rise been adopted by the industry.

92 In competition, a product's price will rise if its marginal cost increases or, under some circumstances, if its demand grows more inelastic. The demand elasticity affects the competitive price if marginal cost pricing does not lead to sufficient producers' surplus to guarantee a normal return to a new entrant (as might occur, for example, if fixed costs of production are high). Under such circumstances, the price of some or all products in the price book will be in excess of marginal cost in a competitive (free entry) equilibrium. The markup over marginal cost will be the largest for those products with the most inelastic demand (although competition will constrain markups through the limitation that an entrant earn no more than a normal return on its fixed investment). For this reason, a rise in marginal cost or a reduction in the elasticity of demand could supply a legitimate business justification for a price increase. A further analysis would be required to determine whether the observed price increase is commensurate with what would be expected under competition given the magnitude of the shift in cost or the elasticity of demand, however. Moreover it will be necessary to take into account the possibility that in competitive equilibrium, the markup over marginal cost may vary with exogenous factors such as the stage of the business cycle. (When price changes follow shifts in cost or demand, the industry equilbrium could also be coordinated; shocks to cost or demand can induce coordinating firms to alter the terms of their understanding, as indicated supra at note 49 , much as they induce a change in the competitive equilibrium.) 
given the assumption that deviation will quickly be detected and punished.

Despite the presence of multiple plus factors, the example presents at most a close case for finding an agreement from the available circumstantial evidence, however. The court would likely be uneasy about reaching the conclusion that the firms agreed on the three percent price increase because of the difficulty distinguishing that inference from the view that the conduct reflected independent decision making. The first firm's five percent increase in price was surely an independent decision, a court could say. The second firm's decision to follow with a lower three percent increase surely was an independent decision as well. The decision by rivals to match, while unfortunate, may not appear suspect. Oligopolists frequently do better by increasing price when their rivals do, rather than by preserving a lower price and hoping to increase their market share at the expense of the rival that increased price. ${ }^{93}$ For the same reason, the first firm's decision to lower its increase to three percent may reflect an independent decision. A court that reasons this way will consider the behavior mere oligopolistic interdependence, not an agreement. ${ }^{94}$ It can defend this conclusion analytically, in terms of the plus factors, by denying that communication has occurred and by deeming legitimate the matching responses of the rivals. In this way, the court would argue that the firms have not engaged in the process

93 See text supra at note 51. For this reason, once a particular outcome among the multiple outcomes possible has been established as focal, the industry moves rapidly to that equilibrium.

94 This inference is strengthened by the fact in the example that the price books took effect on the date they were issued. It is surely a legitimate business practice to communicate prices to customers. Moreover, although it is possible to imagine firms negotiating an agreement by altering prices actually charged to customers, it will be more difficult to infer an agreement under such circumstances than when the firms employ future price announcements in bargaining. But $c f$. Reserve Supply Corp. v. Owens-Corning Fiberglas Corp., 1992-1 Trade Cas. (CCH) I 69,913 (7th Cir. 1992) (advance announcements of increases to prices in price book do not encourage the inference of an agreement to raise price when customers require advance notice). 
that antitrust law deems an agreement because the decisions of the first and second firms to raise price were made with the hopebut not the assurance--that rivals will follow.

The additional argument that comprises the second horn of the first dilemma could tip the balance of this close case against the inference of an agreement. Even though the economic environment is conducive to coordinated behavior-policing of an agreement is feasible by assumption, and terms of coordination can readily be identified through the application of a focal rulethe court may recognize that it may nevertheless be irrational for the firms to agree to fix price. Why should the firms engage in the process of negotiation and the exchange of mutual assurances, and risk antitrust prosecution for their conduct, when the focal rule permits them to achieve a substantial degree of coordination without additional communication? ${ }^{95}$ A court that reasons this way will be unlikely to see communication in the pricing decisions of the firms, and, in consequence, will be unlikely to find plus factors present sufficient to identify an agreement.

As this example suggests, the second horn of the first dilemma is engaged because the very features of the economic environment that make coordination plausible can simultaneously operate to make an agreement unnecessary for that coordination to occur. The logic of this horn of the dilemma emerges from the insights of contemporary economic theory, especially from the idea that focal rules may provide the terms of a coordinated understanding. As courts come to recognize that in an economic environment conducive to coordination it may be irrational for the firms to

95 In contrast with the argument that forms the first horn of the dilemma, this argument is not a sympathetic one for defendants to press because it concedes that the industry is exercising market power. For this reason, defendants can be expected to make it in the alternative, not conceding that the firms are presently coordinating their behavior. Defendants can also be expected to focus attention on the absence of plus factors rather than on the presence of coordination. For example, in an appropriate case a defendant might point out that mere price leadership is not unlawful regardless of whether the industry environment is congenial to coordination and regardless of whether high prices result. 
agree, they can be expected to become more skeptical of inferring an agreement to fix price from circumstantial evidence even when the economic plausibility plus factors are present.

In one important respect, the second horn of the first dilemma is less powerful than the first horn. The logic of the first horn applies to all conduct when the economic environment is not conducive to coordination; in such an environment, the argument runs, an agreement to fix price is never rational. In contrast, the second horn of the dilemma preserves some scope for inferring an agreement to fix price. The gap in the logic of the second horn of the dilemma arises when the economic environment is conducive to coordination, but the observed industry behavior is inconsistent with what would be expected were the firms to coordinate through plausible focal rules. Under such circumstances, the traditional standards for inferring an agreement from circumstantial evidence remain unchallenged by the first dilemma.

Several types of circumstantial evidence will likely be found important in a case in which a court infers an agreement while rejecting defendant's argument, based on the second horn of the first dilemma, that it would be irrational for the firms to agree because the forbidden process is unnecessary for successful coordination. First, some behaviors are so complex that it is implausible that they would be observed absent concerted industry action. Plausible focal rules are likely to be simply stated and readily grasped (e.g., raise all prices a common percentage or dollar amount, or reduce output by a common percentage). ${ }^{96}$ Such focal rules will likely be sufficient to generate the observed behavior of many oligopolies, perhaps including the conduct of firms selling a single, homogeneous product in a single geographic market. Yet in other oligopolies, such as those in which some firms prefer a high price for some products while other firms prefer a high price for other products, many complex bargains among the sellers may be unreachable by coordinating firms employing plausible focal rules. If the observed conduct is more complex than behavior con-

96 Were the coordination rule instead complex, it would be difficult for it to become self-evident absent the process of agreement. 
sistent with those plausible focal rules that would characterize coordination in the absence of an agreement, then the inference that the conduct arose from concerted action is strengthened.

Second, if the observed conduct lacks a plausible business justification, it is unlikely that it arose from independent decision making. For this reason, a weak or pretextual business justification strengthens the inference that an agreement to fix price, tacit or express, had been reached. Third, if the rivals communicated directly, or had the opportunity to do so, and if rival behavior changed immediately following that communication or opportunity, the inference that an agreement was reached is also strengthened. ${ }^{97}$

In the hypothetical case discussed above, the inference of an agreement can be strengthened with facts consistent with these types of evidence. Suppose that instead of announcing an acrossthe-board price increase, the first firm issued a partial modification of its price book. In the substitute pages, it raised the price of some products, lowered the price of others, and left many prices alone. It further announced that the new prices would not take effect for 2 months. Now suppose the industry jockeys over price much as it did before. The second firm announces its own set of modifications, not identical to those the first firm announced but involving many of the same products, to take effect in the future. The other firms follow the second firm, and the first firm goes along by changing its modification to be identical to that adopted by the second firm. This common set of modifications is developed during the 2-month period after the first modification was announced. After 2 months go by, each seller's modified price book takes effect.

On these facts, the inference of agreement is stronger than it was before, and an agreement might well be found by a court. The

97 These examples are illustrative, not exhaustive. The inference that the firms agreed would also be strengthened, for example, by traditional legal evidence of conspiracy, such as evidence that the conspirators met in a hotel room or evidence that they adopted the common price books with the intent of facilitating coordination. 
resulting arrangement is a complex bargain, changing a host of relative prices. It is difficult to imagine that this result would arise without the process of agreement, even if all the negotiations take place in public through issuing price books and press releases..$^{98}$ These facts would make it difficult for a defendant to argue that an agreement is unnecessary for the firms to arrive at the observed conduct. Moreover, the fact that the price jockeying took place with proposed prices that did not take effect until after the negotiations were completed would undercut an argument that the practices had a legitimate business justification, 99 as would the assumption that the price changes occurred in the absence of changes in cost or the elasticity of product demand. ${ }^{100}$ With addi-

98 Cf. 6 P. AREEDA, supra note 58, at I 1425a (if the defendants "could not or would not have acted as they did without advance communication and understanding, then their action necessarily proves a traditional conspiracy"); but cf. id. at \ $1425 \mathrm{~d} 4$ (idiosyncratic pricing formula could have been adopted independently by firms acting sequentially). The inference of an agreement would be especially compelling if the price changes in the proposed modifications raise many prices significantly relative to the price increases that would result from the application of a plausible focal coordination rule. (A bargain more complex than what plausible focal rules make feasible will raise joint industry profits as well as some prices, but it may be impossible to determine whether profits have increased because economic profits are difficult to infer from accounting data.)

99 Advance price announcements may have legitimate business justifications, as when they are desired by buyers to reduce the costs of searching for the best price. But the fact that buyers accelerate purchases when price increases are announced does not necessarily legitimate the practice or count against finding an agreement. Such buyer behavior would be observed regardless of whether the firms are acting independently or concertedly; even the customers of a monopolist would be delighted to receive advance notice of price changes. In any event, there may be other, potentially less restrictive ways of providing buyers with price protection, such as allowing buyers to purchase in advance of delivery.

100 The fact that the price modifications were limited to some but not all products, rather than taking the form of issuing a new price book in its entirety, probably strengthens the case for finding an agreement. This method of communication serves to highlight those price changes under 
tional circumstantial evidence of agreement, moreover, the case for inferring an agreement from circumstantial evidence, already strong, could be made overwhelming. ${ }^{101}$

As this example demonstrates, the second horn of the dilemma does not purport to rule out all possibility that the firms have reached an agreement. In this respect, the second horn stands in contrast with the first horn of the dilemma, which leads to an unqualified inference of the irrationality of an agreement. ${ }^{102}$ Nevertheless, the second horn will apply and make a court reluctant to infer an agreement from circumstantial evidence in many cases in which that inference would readily have been made previously.

negotiation. But this anticompetitive interpretation of the form of the negotiations is weakened if it would be markedly more expensive to reissue the full price book than to issue substitute pages; this latter assumption would supply a legitimate cost-based explanation for the practice.

101 Such additional evidence might include, for example, a demonstration that retailers and ultimate consumers pay little or no attention to advance price announcements (further undercutting the possibility of a business justification), evidence that the firms met at a trade association during the brief time between the first firm's price modification announcement and the second firm's adjustment to that proposal (direct communication), or testimonial or documentary evidence that the price book modifications were issued with an intent to coordinate. $C f$. In re Coordinated Pretrial Proceedings in Petroleum Prods. Antitrust Litig., 906 F.2d 432 (9th Cir. 1990) (a jury could find an agreement to fix price from evidence of parallel pricing, direct contacts among defendants, advance price announcements, posting of prices in unusual detail, the absence of a business justification for advance price announcements, and evidence that these practices were intended to lead to higher prices), cert. denied, 111 S. Ct. 2274 (1991); 6 P. AREEDA, supra note 58, at I1 $1435 \mathrm{~g}$ ("even lawful unilateral action involving price books might be enough to tip the balance toward a conspiracy finding" when, for example, "competitors hold meetings after a departure from uniform pricing").

102 In industries in which the first dilemma undercuts the inference of an agreement, successful prosecutions of horizontal restraints under § 1 will be more likely to rely on direct evidence of an agreement, or take the form of a challenge to an obvious concerted industry practice as unreasonable, rather than attempt to prove an agreement from circumstantial evidence. 
As antitrust law recognizes the significance of recent developments in economics, the first dilemma for Sherman Act $\S 1$ enforcement emerges. Stigler's insights about oligopoly led to the emergence of the first horn of the dilemma, and contemporary developments in oligopoly theory create the conditions in which the logic of the second horn may become more apparent. The first dilemma explains why it might be irrational for firms to reach an agreement, even when the traditional plus factors indicative of a secret conspiracy are present. This dilemma has scope to flower because the legal idea of an agreement is about a different phenomenon than the economic idea of a coordinated equilibrium outcome: the legal idea of an agreement describes a process by which an industry reaches an economic outcome in the marketplace, while the economic idea of an equilibrium describes the outcome itself. 103

In the wake of Stigler, it may have appeared possible to bridge the distinction between these legal and economic ideas. The distinction between competition and cooperation embodied in a Stiglerian one-shot game might appear isomorphic to the distinction antitrust law makes between an illegal agreement and mere interdependent oligopoly behavior. But the contemporary economic idea of coordination, arising from the repeated game framework, helps clarify the difficulty of sustaining a simple correspondence between the legal and economic ideas.

The economic idea of coordination does have one point of commonality with the legal idea of an agreement. Under the economic definition of coordination, firms are coordinating if, in equilibrium, they adopt strategies that depend on history. ${ }^{104}$ For example, a firm that commits to punish a rival in the next period if the rival deviates from the terms of coordination this period will determine its price and output decisions through a strategy that depends on history. This idea might form part of the intuitive concept of an agreement in conspiracy law. But it is difficult to

\footnotetext{
103 See supra at notes 73-74 and accompanying text.

104 Coordination is defined supra at note 22.
} 
work up much enthusiasm for the view that the legal idea of an agreement to fix price is or should be equated with this economic idea of coordination, ${ }^{105}$ for two reasons. First, it would take a refined and educated imagination to conceive of the intuitive legal idea of negotiating an agreement as tantamount to adopting a strategy dependent on history. Second, if antitrust were to deem coordinated behavior in the economic sense to be the essence of a violation of Sherman Act $\S 1$, it would be nearly impossible in practice to demonstrate a $\S 1$ agreement from circumstantial evidence. The difference between conduct that would violate the statute (carrying out a previously developed strategy in which a firm's behavior depends on history) and lawful conduct (adopting single period strategies while responding to what is learned from the past about the cost or demand curves facing a firm and its rivals) is subtle at best. Developments in economics are likely to make courts more reluctant to infer an agreement to fix price from circumstantial evidence not by altering antitrust law's definition of an agreement, but, as indicated by the first dilemma, by highlighting features of the economic environment that make implausible the inference that the legal definition has been satisfied.

\section{The second dilemma: addressing the oligopoly problem}

A second dilemma for antitrust policy arises as a consequence of the emergence of the first dilemma. On the one hand, the first dilemma implies that it is likely to become more difficult to prove an agreement to fix price from circumstantial evidence. On the other hand, as will be explained in this section, contemporary developments in economics, including the theoretical developments that gave rise to the first dilemma, suggest that the oligopoly problem is more serious than previously thought.

From a theoretical economic perspective, the folk theorem emphasizes that concentrated industries are more hospitable to

105 But cf. Yao \& DeSanti, supra note 7, at text accompanying notes 58-64 (examining possible observable distinctions between one-shot and repeated games). 
coordination, and to achieving higher than competitive prices, than they appeared to Chicago-oriented commentators heavily influenced by Stigler. This view from theory is confirmed by what can be inferred about business practice from the lectures of academic business strategists. Business school faculty teaching strategy routinely counsel their students that managers working for oligopolists should implement practices that would facilitate coordination. 106

Recent empirical industrial organization economics research also confirms that oligopolies are often able to exercise significant market power. The development in the 1980s of new empirical statistical techniques for measuring market power in individual industries frequently permits more precise inferences about the performance of specific oligopolies than were available from prior studies employing older empirical approaches. ${ }^{107}$ These

106 The standard business school case examines the strategies of General Electric and Westinghouse in the years following their criminal price-fixing convictions. E.g., M. Porter, Cases in Competrtive Strategy 102-18 (1983). To raise prices without express negotiation, the firms introduced standardized product definitions, published price books, and committed themselves to buyer protection policies (meeting competition and most favored nations clauses). Proposed Modification of Existing Judgments, U.S. v. General Electric, 42 Fed. Reg. 17,004 (1977). Some teaching this case suggest that mere "signaling" (as through the publication of price books after standardizing product definitions) is sufficient for the industry to achieve high prices; others emphasize the need to deter cheating (for example, by adopting buyer protection policies). $C f$. M. PORTER, supra note 38, at 93-95 (encouraging firms to seek to improve all firms' positions by employing active market signaling through announcements, selective advertising to discipline recalcitrant rivals, and price leadership); id. at 106 (advocating standardization to simplify industry prices and other decision variables so that a focal point can be established for the industry).

107 The older empirical tradition emphasizes the cross-industry relationship between performance measures and concentration. Studies adopting this approach show some tendency for price-cost margins to increase with concentration, but little relationship between concentration and profits. Schmalensee, Inter-Industry Studies of Structure and Performance, in HANDBOOK OF INDUSTRIAL ORGaNIZATION 976, 988 (R. Schmalensee \& R. Willig eds. 1989) (Stylized Facts 4.5, 5.1). While 
studies show that a great deal of market power exists in some concentrated industries, and that anticompetitive conduct is a significant cause of high price-cost margins. ${ }^{108}$ Oligopolies may not inevitably charge supracompetitive prices, but, as contemporary developments in economic theory suggest, and both business practice and the results of applying new empirical tools confirm, oligopolistic coordination is a genuine concern in many concentrated industries.

Post-Stiglerian theoretical economic insights-the recognition that repeated games are more conducive to coordination than oneshot games, the recognition that coordination may be imperfect and incomplete, and the recognition that focal rules simplify the task of reaching the terms of coordination-combine with the empirical evidence developed from the application of new econometric tools for identifying and measuring market power and the evidence about business practice to renew antitrust's traditional concern about the breadth and significance of the oligopoly problem. Antitrust's second Sherman Act $\S 1$ dilemma is that this renewed concern about the performance of oligopolies has arisen at the same time the traditional tool for addressing the oligopoly problem, the horizontal agreement prohibition of the Sherman Act, has become less potent through the operation of the first dilemma.

these results are consistent with the view that some oligopolies are able to exercise market power, the severe methodological difficulties with this approach make it difficult to have confidence in that inference. Profits and price-cost margins can be positively related to concentration either because concentration allows industries to exercise market power, or because firms with low costs simultaneously grow large in market share and receive high profit margins. Moreover, the performance data employed in these studies are suspect because accounting measures of both profits and marginal costs are typically poor proxies for the relevant economic concepts. Comparisons of prices in different markets in the same industry address this latter difficulty in part, however, to the extent the assumption that costs are identical across markets is plausible.

108 Bresnahan, supra note 53, at 1052-53 (conclusions A and B); see Baker and Bresnahan, supra note 76 (collecting more recent studies). 


\section{Two antitrust remedies: merger enforcement and rulemaking}

This section examines two methods for addresssing the oligopoly problem that supplement the use of Sherman Act § 1, antitrust law's traditional tool for policing oligopoly conduct. The discussion of merger enforcement, the first such method, emphasizes the way contemporary developments in economics may permit courts and enforcers to differentiate those acquisitions likely to make coordination worse from those likely to destabilize coordination. The discussion of rulemaking, the second remedial approach, examines the ability of the Federal Trade Commission to prohibit practices facilitating oligopoly coordination in individual industries by rule. The limitations of Sherman Act $\S 1$ highlighted by the second dilemma increase the importance of employing alternative remedial tools such as these to address the oligopoly problem.

\section{A. Addressing the oligopoly problem through merger enforcement}

Clayton Act $\S 7$ 's prohibition of mergers that tend to "lessen competition" or "create a monopoly" 109 permits courts to interdict changes in market structure that would facilitate coordination. ${ }^{110}$ Moreover, no large merger can be consummated until government enforcers have been given an opportunity to review the acquisition for possible violations of this statute. ${ }^{11}$ These merger review statutes give antitrust enforcers the opportunity to examine the structure and behavior of a wide array of industries, to identify those markets with a structure congenial to coordination, and to

109 15 U.S.C. $\$ 18$ (1988).

110 The 1992 Horizontal Merger Guidelines of the government enforcement agencies also recognize that antitrust law reaches acquisitions likely to lessen competition through altering the unilateral behavior of the merged firm. Supra note 16, at § 2.2.

111 U.S.C. § 18a (1988) (Hart-Scott-Rodino Act). 
determine whether proposed acquisitions are likely to make coordination more effective or more complete. By challenging acquisitions likely to enhance coordination, while permitting acquisitions likely to destabilize coordination, antitrust enforcers can improve the functioning of some oligopoly industries. This tool for addressing the oligopoly problem is limited, however, because it can only be applied to firms that seek to merge.

The judicial approach to determining whether proposed acquisitions are likely to lessen competition by enhancing coordination has long been influenced by developments in economics. When the structural school was dominant, courts and enforcers exhibited a great deal of hostility toward increases in concentration in oligopoly industries, even if those increases were small. ${ }^{112}$ Merger analysis in the courts and enforcement agencies has been transformed in the last decade, however, as it has come to embrace Stigler's insights into oligopoly behavior. Stigler's approach has permitted courts and enforcers to analyze the plausibility of coordination industry-by-industry, and so to determine, for example, whether entry would undercut the exercise of market power or whether firms would refuse to coordinate for fear of rival cheating. Both the enforcement agencies and the courts now approach merger review by undertaking a detailed fact-intensive analysis of market structure and conduct in order to determine whether coordination could be successful. Courts are no longer reluctant to allow sizable acquisitions in a concentrated industry if their economic analysis demonstrates that the industry is not susceptible to the exercise of market power. ${ }^{113}$

Stigler's insights into oligopoly behavior gave courts and enforcers a method for identifying individual industries in which coordination was unlikely regardless of concentration. But once

112 United States v. Philadelphia Nat'l Bank, 374 U.S. 321 (1963); 1968 Department of Justice Merger Guidelines, 4 Trade Reg. Rep. (CCH) I 13,101 .

113 E.g. United States v. Baker Hughes, Inc., 908 F.2d 981 (D.C. Cir. 1990); United States v. Waste Management, Inc., 743 F.2d 976 (2d Cir. 1984). 
an industry was identified as one in which coordination was economically plausible, the Stiglerian analysis offered little basis for discriminating between those mergers likely to enhance coordination and those not likely to do so. In consequence, the structuralist presumption that the likelihood of anticompetitive conduct increases with concentration has remained important in merger analysis, albeit only with respect to those industries in which the economic environment is conducive to coordination. ${ }^{114}$ As a strategy for addressing the oligopoly problem, this approach to merger enforcement is defensive. ${ }^{115}$ The presumption of anticompetitive effect from nontrivial increases in concentration in industries susceptible to coordination aims to keep oligopolies from performing worse, but not to distinguish mergers likely to destabilize existing coordination from those likely to enhance coordination.

Contemporary developments in economic theory offer the promise of allowing courts and enforcers to take the offensive in exploiting merger policy to address the threat of oligopoly coordination. ${ }^{116} \mathrm{~A}$ fourth insight about oligopoly behavior derived from

114 United States v. Baker Hughes, Inc., 908 F.2d 981 (D.C. Cir. 1990); see 1992 Merger Guidelines, supra note 16, at § 1.51 .

115 Cf. 6 P. AREEDA, supra note 58, at $\llbracket 1432 \mathrm{~d} 5$ (describing the "containment" approach of addressing the oligopoly problem through prohibiting concentrating mergers and facilitating practices).

116 Other developments in economics make the presumption of anticompetitive effect arising from increases in concentration appear less attractive today than 30 years ago. The empirical literature does recognize some tendency for price-cost margins to increase with concentration on average across industries. Schmalensee, supra note 107, at 988 (Stylized Fact 5.1). But the weakness of this statistical relationship suggests that the specific attributes of the industry and the nature of the increase in concentration play a leading role in determining whether any given merger will enhance coordination. Accordingly, while enforcement decisions based solely on applying a presumption of anticompetitive effect from concentration may be correct on average, their precision can likely be improved substantially by incorporating information about the specific industry and the specific acquisition. Moreover, while many if not most theoretical models of oligopoly behavior predict higher prices from increases in market concentration, economic theorists now treat concen- 
post-Stiglerian developments in economic theory can be exploited to predict the effect on coordination of specific mergers within industries in which coordination is economically plausible. To the extent enforcers and courts can learn to make such predictions with confidence, they can prohibit those mergers likely to make coordination more effective or more complete, while permitting those mergers likely to destabilize existing coordination.

The fourth contemporary economic insight into oligopoly behavior is that certain firms-mavericks-may limit the ability of their industry to coordinate more completely. A firm need not behave disruptively to play this role. Rather, certain specific firms may constrain more effective coordination, without ever deviating from the terms of the coordinated agreement, even though other firms in the oligopoly would be willing to make coordination more effective. ${ }^{117}$ Especially when coordination is based on focal rules, it is likely that a single firm (or a few similar firms) will constrain coordination in this way.

Mavericks are likely to exist in coordinated equilibria when firms differ in significant ways. Whatever the focal coordination rule, some firms will benefit from cheating more than will others.

tration as much as the result of the way firms invest and interact (including their exercise of market power), than as a cause or indicator of market power. E.g., J. Sutton, Sunk Costs and Market Structure: Price Compettition, Advertising, and the Evolution of Concentration (1991).

117 Cf. Harrington, The Determination of Price and Output Quotas in a Heterogeneous Cartel, 32 INT'L EcON. REv. 737 (1991) (when the coordinated equilibrium is selected to satisfy the Nash bargaining solution, the equilibrium price may decline as the high-cost firm's costs increase). The maverick need not be the firm that attempts to change the terms of the coordinated understanding by establishing a new focal equilibrium (e.g., the price leader), although it could play this role. See Rotemberg \& Saloner, Collusive Price Leadership, 39 J. Indus. Econ. 93 (1990). If a firm would find the competitive outcome more profitable than its earnings under any plausible focal rule, see supra at note $8 \&$ note 48 , and if the remaining firms would not find coordination profitable were that firm excluded from the coordinated understanding, the firm is in effect a maverick so powerful as to inhibit coordination altogether. 
Whatever the set of credible punishments with which the coordinating firms would threaten cheaters, those punishments will hurt some firms more than others. ${ }^{118}$ Hence, given the coordination rules that define the high price outcome and the punishment threat, some firms will likely have little temptation to deviate after comparing the benefits of cheating to the cost, while other firms will find themselves nearly indifferent. Those firms that are nearly indifferent constrain the effectiveness of coordination more than do those rivals for whom it is an easy decision to adhere to the coordinated arrangement. ${ }^{119}$

The 1992 Horizontal Merger Guidelines recognize this point by noting that certain structural characteristics might give a firm "a greater economic incentive to deviate from the terms of coordination than do most of their rivals." 120 The Guidelines provide three examples. First, if many firms in a market face capacity constraints, a firm with an atypically large amount of excess or divertable capacity in relation to its sales or total capacity may gain the most from deviation, and therefore have the greatest incentive to cheat. Second, a firm might have a larger incentive to cheat than its rivals if it is able to expand sales cheaply through captive production for a downstream affiliate. Third, a firm might be more willing to deviate in a market in which products are differentiated if its products are considered close substitutes by the current customers of its rivals. These examples do not exhaust the set of plausible structural attributes of a maverick. ${ }^{121}$

118 For example, if punishment would require all firms to expand output by the same percentage, firms with predominately high-cost excess capacity may find their assigned punishment role more expensive than do their rivals of low-cost excess capacity.

119 If the firms were able to agree on the joint profit-maximizing outcome, most likely all would simultaneously be indifferent between following the terms of coordination and deviating from those terms. In this limiting case, all firms would constrain more effective coordination equally and each would be a maverick.

1201992 Merger Guidelines, supra note 16, at § 2.12.

121 In vertically-related markets in which both upstream and downstream prices are in excess of cost, a firm that participates more in the 
The idea of a maverick permits courts and enforcers to identify whether a particular merger in an industry congenial to coordination is likely to lessen competition by enhancing coordination. An acquisition in the market can lessen competition by altering the incentives of a maverick to go along with the terms of a coordinated understanding rather than deviate from them. If a binding constraint on the success of coordination is thereby relaxed, more effective or more complete coordination can emerge. This result can occur in two ways. ${ }^{122}$

First, a maverick may be one of the parties to the acquisition. For example, suppose the constraint on enhanced coordination comes from a small firm with a low rate of capacity utilization. This firm may have a substantial incentive to employ its excess capacity to cheat. Its acquisition by a large firm with a higher degree of capacity utilization will likely create a merged firm with a utilization rate closer to the large firm's premerger utilization rate than to the small firm's rate. The result may be to shift the identity of the firm that constrains enhanced industry coordination, from the acquired firm to the industry participant with the lowest utilization percentage after the merger. If the new constraining firm would accept a significantly higher price before becoming nearly indifferent to following the terms of the coordinated understanding or deviating from them, this merger will

downstream market than in the upstream market (by buying from other upstream producers more of the upstream product than it produces captively) is likely to have a greater incentive to deviate on a coordinated understanding limited to raising the upstream price than would an upstream producer whose primary loyalty is to the upstream market. See B.F. Goodrich, 5 Trade Reg. Rep. (CCH) I 22,519 at 22,161-66 (1988). Other examples might involve structural factors affecting the incentives of firms not to go along with the punishment that would be required in the event deviation were to occur. For example, a firm with little excess or divertable low cost capacity may be the least willing to participate in the output increase that might be required to punish deviation.

122 In the examples below, the maverick is nearly indifferent between going along with the high price arrangement or deviating from it. Similar examples could be created in which the merger affects the incentives of a firm nearly indifferent to participating in the necessary punishment. 
likely lead to that higher price. More generally, the merged firm may reduce the constraint on oligopoly coordination relative to the constraint posed by one of the merger partners before the acquisition, and so relax the binding constraint on coordination in the marketplace. ${ }^{123}$

Second, the merger of nonmaverick firms may alter the incentives facing a maverick, thereby enhancing coordination. If an acquisition lowers the marginal production costs of the merger partners, for example, the merged firm may find its assigned punishment role less costly than the merger partners previously found. On the margin, the merged firm may become willing to punish more severely, should any rival deviate. ${ }^{124}$ Recognizing this, the maverick will be less willing to cheat than before. In consequence, coordination will be enhanced without inducing the maverick to deviate. The merger again relaxes the binding constraint on oligopoly coordination, leading to higher prices. ${ }^{125}$

Other mergers in the same industries might destabilize existing coordination, even though they increase concentration. For example, a merger involving a maverick might lower the merged

123 Even if the merger does not change the identity of the firm that constrains coordination, it may relax the constraint imposed by the maverick, and so raise the equilibrium price, for example by giving the maverick an incentive to increase price unilaterally. See 1992 Merger Guidelines, supra note 16 , at $\S 2.2$.

124 Punishment need not involve a price below cost in order for the merger to make punishment less costly, as discussed supra at notes 26-27 and accompanying text. The punishment price will likely be in excess of marginal cost if punishment takes the form of a return to a static noncooperative equilibrium; price exceeds marginal cost, for example, in homogeneous product Cournot equilibrium, differentiated product Bertrand equilibrium, and homogeneous product Bertrand equilibrium when marginal costs are rising.

125 The lower production cost in the example may constitute a social benefit that could be weighed against the enhanced coordination in an efficiency calculus. In the example, the industry price will likely rise with merger, despite the efficiency, because the merging firms do not constrain coordination so are not induced to deviate by the cost reduction. 
firm's marginal cost of production and distribution. Such a merger could enhance competition by tightening an already binding constraint on coordination. Alternatively, a merger involving nonmaverick firms may cause those firms to become less willing to punish a deviating rival. ${ }^{126}$ This result might arise, for example, if large firms in the industry are expected to bear a disproportionately high share of the expenses of punishing deviation. In this setting, a maverick may be encouraged to price more aggressively by an acquisition that turns two small nonmaverick sellers into a large nonmaverick rival. Then the merger will increase the constraint the maverick places on industry coordination. These more competitive outcomes are unlikely to constitute the motive for merger, because the enhanced competition will tend to lower profits by lowering the market price. But increased competition may nevertheless arise as the fortunate consequence of an acquisition motivated by the desire to achieve efficiencies, particularly when the efficiencies accrue in markets other than those in which coordination is destabilized. ${ }^{127}$

These examples show how the idea of a maverick provides a basis for explaining why the particular increase in concentration proposed in a specific acquisition will enhance or reduce the ability of an industry to coordinate. In this way, developments in economic theory offer the promise of allowing antitrust enforcers to distinguish those acquisitions likely to enhance coordination from those likely to destabilize coordination, based on an analysis of the transaction that goes beyond the traditional presumption that an increase in concentration facilitates coordination on average. To the extent this promise can become a reality, ${ }^{128}$ it will provide

126 See, e.g., Davidson \& Deneckre, Horizontal Mergers and Collusive Behavior, 2 INT'L J. INDUs. ORG. 117 (1984).

127 Accordingly, the possibility that coordination would be destabilized provides no basis for justifying a merger that does not generate efficiencies in some market.

128 It will not always be possible to obtain sufficient information about the specific market and merger at issue to determine the identity of the industry's mavericks and whether the merger will enhance or reduce the incentives of a maverick to coordinate. Under such circumstances, 
courts and enforcers with an improved tool with which to address the oligopoly problem.

\section{B. Addressing the oligopoly problem through rulemaking}

For more than three decades, courts and commentators evaluating parallel conduct under Sherman Act $\S 1$ have felt frustration that the mere exercise of market power by a firm or group of firms cannot be made illegal. ${ }^{129}$ Without proof of an agreement, Sherman Act $\S 1$ is not violated. An unsuccessful legislative effort to secure no-fault demonopolization and a largely academic suggestion that Sherman Act $\S 2$ be read to apply to shared monopolization, both dating from the late 1960 s and early 1970 s, were well-intentioned but fundamentally unworkable efforts to end this frustration. ${ }^{130}$

The prior legal approaches to addressing the social harm of oligopoly foundered on two difficulties. The first difficulty, affecting both remedial approaches, is that the social costs of dissolving large enterprises are substantial. These include the loss in scale and scope economies, the litigation costs required to demonstrate at trial that the industry at issue is exercising market power, and the cost of disrupting the economic activities in which the organization is engaged.131

courts and enforcers can be expected to continue to employ a structural merger policy, hostile to significant increases in concentration in oligopoly markets conducive to coordination.

129 A similar frustration has infected Sherman Act $\S 2$ jurisprudence. The offense of monopolization requires proof of an overt act harmful to competition as well as proof of monopoly power, to avoid prosecuting a successful firm that has achieved a high market share or high price-cost margin through "superior skill, foresight, and industry." United States v. Aluminum Co. of America, 148 F.2d 416, 430 (2d Cir. 1945); accord, United States v. Grinnell Corp., 384 U.S. 563, 570-71 (1966).

130 These initiatives are described supra at note 56.

131 Although antitrust accepts similar social costs in prohibiting mergers likely to lessen competition, such costs are much greater when firms are dissolved than when a curative divestiture resolves an otherwise anticompetitive merger. In the merger context, structural relief usually 
The second difficulty applies to all efforts to attack oligopolies through adjudication-whether seeking to deem oligopolistic behavior an agreement under Sherman Act $\$ 1$, monopolization under Sherman Act $\S 2$, or an unfair method of competition under Federal Trade Commission Act $\S 5$. Antitrust adjudication requires proof that each defendant violated the law through some anticompetitive act; the mere demonstration that firms have exercised market power is insufficient to hold a firm liable for its past conduct. ${ }^{132}$ Accordingly, antitrust liability requires, in addition to proof of market power, proof of concerted action under Sherman Act $\S 1$, proof of a deliberate bad act under Sherman Act $\S 2,133$ and, according to one appellate panel, proof of an agreement or other indicator of oppressiveness under FTC Act $\S 5.134$

affects only one firm; in contrast, industrial restructuring could involve an entire industry. Moreover, merging firms are typically not permitted to integrate their operations until a governmental challenge is resolved. Hence, if structural relief is required in the merger context, it can often be accomplished by the sale of a division of one of the merger partners, without disrupting an existing economic organization. Moreover, when the anticompetitive aspects of the transaction affect only a small part of the activities of the merging firms, and when they do not affect the activities central to the business motivation for the transaction, the firms themselves often offer their internal expertise in a largely nonadversarial negotiation to identify ways of carving out the necessary divestitures without sacrificing scale and scope economies. This process, available only in the review of mergers, also helps minimize the litigation costs associated with the divestiture.

132 If a horizontal restraint is deemed "naked," so that the per se rule of Sherman Act $\S 1$ applies, however, market power is presumed to exist without need for demonstration. See NCAA v. Bd. of Regents, 468 U.S. 85 (1984); Broadcast Music, Inc. v. Columbia Broadcasting Sys., 441 U.S. 1 (1979).

133 See generally, ABA ANTITRUST SECTION, supra note 53, at 195259.

134 Ethyl, 729 F.2d at 139. But see infra at notes $142-47$ and accompanying text (questioning this holding). The appellate panel suggested that evidence of anticompetitive intent or the absence of a legitimate business justification might provide the necessary indicia of oppressiveness. 
In each case, no individual firm is held liable for its past behavior unless it had the choice of acting otherwise. Because it is often difficult for plaintiffs or prosecutors to prove such an anticompetitive act, especially to the extent the first dilemma is troublesome to courts, the oligopoly problem has to a significant extent become immune from attack through adjudication under these antitrust laws. ${ }^{135}$

Regulation through rulemaking addresses both problems. Instead of dissolving firms, the regulatory approach proscribes certain specified conduct in a particular industry, such as a practice that facilitates coordination in that industry, regardless of whether the practice is unilateral or coordinated. ${ }^{136}$ Rules can generally be tailored more carefully than divestitures to avoid forcing firms to give up scale and scope economies in production. Moreover, rulemaking avoids the need to prove an anticompetitive act because it attacks a harmful practice prospectively. Although evidence of the effect of past conduct is typically relied upon to prove future harm, rulemaking does not seek to hold specific firms liable for past behavior. ${ }^{137}$ A firm engaged in the challenged practice is not accused of moral culpability and is not exposed to punishment for past conduct. ${ }^{138}$ As with all regulation, a rule pro-

135 It may sometimes be possible to expand the reach of traditional adjudication through creative advocacy, however. Practices facilitating coordination that are incorporated in contracts between sellers and their customers, such as price protection clauses, can be challenged under Sherman Act $\S 1$ despite the absence of an agreement among the sellers if the vertical contracts incorporating the price protection provision are found to satisfy the agreement requirement of $\S 1$. Simons, Fixing Price with Your Victim: Efficiency and Collusion with Competitor-Based Formula Pricing Clauses, 17 Hofstra L. Rev. 599, 630 (1989).

136 For examples, see note 157 infra and accompanying text.

137 A rule applies to all firms, including those entering the market after it takes effect. In contrast, an adjudication applies only to those firms named as defendants.

138 Cf. Official Airline Guides, Inc. v. FTC, 630 F.2d 920 (2d Cir. 1980), cert. denied, 450 U.S. 917 (1981) (in an adjudication, the FTC cannot condemn a respondent's conduct as unfair when the defendant has 


\section{0 : The antitrust bulletin}

hibiting the prospective employment of a specific practice merely reflects a policy judgment, based on an evidentiary record developed with procedural protections to the firms that will be affected, that the industry would likely perform better if the practice were changed.

The Federal Trade Commission already has the power to promulgate rules prohibiting unfair methods of competition, ${ }^{139}$ although it has rarely exercised that power. ${ }^{140}$ The Commission's rulemaking power most likely permits it to address oligopoly behavior by challenging practices facilitating coordination through informal rulemaking, regardless of whether the practices were adopted collectively or unilaterally. The expansive language of one appellate opinion makes this an open question, however. In the 1984 Ethyl decision, a Second Circuit panel held that "before business conduct in an oligopolistic industry may be labelled 'unfair' within the meaning of $\S 5$, a minimum standard demands that, absent a tacit agreement, at least some indicia of oppressive-

no anticompetitive motive and no ability to profit from the alleged reduction in competition).

139 The FTC's power to issue rules proscribing unfair methods of competition derives from 15 U.S.C. \& 46(g) (FTC Act \& 6(g)). Nat'l Petroleum Refiners Ass'n v. FTC, 482 F.2d 672 (D.C. Cir. 1973), cert. denied, 415 U.S. 951 (1974); see Order Denying Petition No. 5 of the Nat'l Fire Protection Ass'n, 1979-1983 Transfer Binder, Trade Reg. Rep. (CCH) 21,771 (1980). Its competition rulemaking power is exercised pursuant to the informal procedures delineated in Administrative Procedure Act, 5 U.S.C. $\$ 553$ (1988); see 15 U.S.C. § 57a(a)(2) (1988) (Magnuson-Moss amendments do not apply to rules proscribing unfair methods of competition). Rules are issued after notice and comment, with an oral hearing at the discretion of the Commission, and with a statement of findings and reasons. 16 C.F.R. \$§ 1.21-1.26 (1992) (FTC rulemaking procedures for rules promulgated pursuant to authority other than the Magnuson-Moss Act). The Commission enforces rules promulgated pursuant to the Administrative Procedure Act (APA) by issuing a cease and desist order, and by seeking contempt sanctions in federal court if that order is violated. 15 U.S.C. § 45(b) (1988) (FTC Act § 5(b)).

140 Report of the American Bar Association Section of Antitrust Law Special Committee to Study the Role of the Federal Trade Commission, 58 ANTTTRUst L.J. 43, 91 n.103 (1989). 
ness must exist such as (1) evidence of anticompetitive intent or purpose ... . or (2) the absence of an independent legitimate business reason for [the] conduct."141 Because the FTC's rulemaking power in competition cases derives from its powers under FTC Act $\S 5$, Ethyl could be read to require the Commission to identify an agreement or other indicator of oppressiveness before it prohibits an unfair practice by rule as well as by adjudication.

It would not be surprising if other circuits refused to read the requirement of oppressiveness into the FTC Act, however, even in the context of an adjudication, for two reasons. First, the Supreme Court has long recognized that the prohibition against "unfair" conduct in FTC Act $\S 5$ is extremely broad, reaching conduct that also violates the Sherman Act or Clayton Act, conduct that violates the "spirit" of those antitrust laws, and conduct that offends public values beyond the letter or spirit of the antitrust laws. ${ }^{142}$ Although the practices that the FTC sought to proscribe in the Ethyl litigation did not violate the Sherman Act, because they were adopted unilaterally by the firms, only with a remarkably constricted view of the "spirit" of the antitrust laws could the Second Circuit panel hold that the statute did not reach the challenged practices. ${ }^{143}$ Contrary to the appellate panel's view, the

141 E.I. du Pont de Nemours \& Co. v. F.T.C., 729 F.2d 128, 139 (2d Cir. 1984) (Ethyl). In the Ethyl litigation, the FTC sought to prohibit three practices adopted unilaterally by four manufacturers of lead antiknock gasoline: selling the product at a delivered price (including transportation costs), giving customers advance notice of price increases, and agreeing to "most favored nation" provisions in contracts with customers (guaranteeing that no other customer would be charged a lower price). The Commission argued that these practices facilitated supracompetitive pricing.

142 FTC v. Ind. Fed'n of Dentists, 476 U.S. 447, 454 (1986); FTC v. Sperry \& Hutchinson Co., 405 U.S. 233, 244 (1972); FTC v. Brown Shoe Co., 384 U.S. 316, 320-21 (1966); FTC v. Motion Picture Advertising Serv. Co., 344 U.S. 392, 394-95 (1953).

143 The Commission found that the challenged practices were unreasonable, after applying under FTC Act $\S 5$ the analytic approach required by the "rule of reason" under Sherman Act $\S 1$. It carefully weighed the deleterious effect of the challenged practices in facilitating 
Supreme Court has repeatedly indicated that the FTC may condemn a unilateral act under FTC Act $\S 5$ when an agreement to engage in the identical conduct would violate Sherman Act § $1 .{ }^{144}$

interfirm coordination against their beneficial role in reducing the costs of consumer search. In re Ethyl Corp., 101 F.T.C. 425, 607-44 (1983). Cf. Ethyl, 729 F.2d at 143 (concurring opinion acknowledges that the noncollusive adoption of practices facilitating collusion contravenes the spirit of § 1). But cf. Official Airline Guides, Inc. v. FTC, 630 F.2d 920 (2d Cir. 1980), cert. denied, 450 U.S. 917 (1981) (the FTC may not forbid a monopolist's practices by adjudication under $\S 5$, even though the social harms from the practices outweigh the benefits, when the practices harm competition in a market in which the monopolist does not participate and when the monopolist has no anticompetitive motive).

144 FTC v. Cement Institute, 333 U.S. 683, 721 n.19 (1948) (dictum) (basing point pricing); FTC v. Beech-Nut Packing Co., 257 U.S. 441, 455 (1922) (dictum) (resale price maintenance); see FTC v. Motion Picture Advertising Serv. Co., 344 U.S. 392, 399-401 (1953) (dissent interprets majority opinion as extending FTC Act $\S 5$ to encompass practices that would not violate Sherman Act $\S 1$ because they were unilateral) (exclusive dealing); accord, Triangle Conduit \& Cable Co. v. FTC, 168 F.2d 175, 181 (7th Cir. 1948) (alternative holding) (basing point pricing), aff d, 336 U.S. 956 (1949) (per curiam). In Beech-Nut, the Court upheld the Commission's finding that a chewing gum manufacturer's refusal to deal with discounting dealers violated FTC Act $\S 5$. Although the Commission found that the manufacturer had not entered into an express agreement with its customers to maintain resale prices, FTC v. BeechNut Packing Co., 1 F.T.C. 516, 528 (1919), rev'd, 264 F. 885, 891 (2d Cir. 1920), rev'd, 257 U.S. 441 (1922), the appeals court interpreted the decision below as finding a tacit understanding, $264 \mathrm{~F}$. at 891 , see 1 F.T.C. at 522 (finding that dealers were reinstated only after they provided assurances that they would maintain resale prices), and the Supreme Court may have accepted the appellate view, see 257 U.S. at 456 (enjoining the termination of dealers unwilling to provide assurances of their willingness to maintain designated prices). Alternatively, the Supreme Court may be understood as authorizing the Commission to proceed under $\$ 5$ against a unilateral practice that would have violated the Sherman Act had it been concerted. Under this interpretation, the Supreme Court's Beech-Nut decision is controlling precedent improperly contradicted by the Ethyl holding. For an interpretation of the Supreme Court's Motion Picture decision that suggests this decision is controlling precedent inconsistent with the Ethyl holding, see Kovacic, supra note 7, at text accompanying notes, $210-225$. 
Second, on judicial review of agency actions, the FTC is entitled to deference in its construction of $\S 5$. The Supreme Court has established this rule both as a general principle of administrative law ${ }^{145}$ and as a specific instruction to the appellate courts in reviewing actions of the FTC. ${ }^{146}$ Against this background, it is a challenge to understand the legal basis under which the Ethyl panel imposed the novel legal requirement that the FTC prove an agreement or other indicator of oppressiveness in order to condemn as unfair a practice facilitating collusion in an oligopoly. ${ }^{147}$

145 When a statute is "silent or ambiguous" with respect to a specific legal question, a court may not "simply impose its own construction on the statute" but must instead ask "whether the agency's [interpretation] is based on a permissible construction of the statute." Chevron, U.S.A., Inc. v. Natural Resources Defense Council, Inc., 467 U.S. 837, 843 (1984). Moreover, an agency's construction of a statuțory scheme it must administer should be accorded "considerable weight," especially when the agency's policy choice represents a reasonable accommodation of conflicting policies committed to the agency's care by statute. 467 U.S. at 844. Cf. Dyk \& Schenck, Exceptions to Chevron, 18 Admin. L. News 1 (1993) (describing limitations to the principle of judicial deference to agency interpretation of ambiguous statutes).

146 FTC v. Texaco, Inc., 393 U.S. 223, 225-26 (1968); F.T.C. v. Cement Institute, 333 U.S. 683, 720 (1948); see FTC v. Ind. Fed'n of Dentists, 476 U.S. 447, 454-55 (1986) (when conduct violates FTC Act $\S 5$ because it violates Sherman Act $\S 1$, "some deference" is given to the Commission's "informed judgment," where the latter term encompasses both the agency's "legal rationale" and its "factual findings").

147 Cf. 6 P. AREEDA, supra note 58, at \1436a (Ethyl decision not "definitive" in confining the reach of FTC $\S 5$; some unilaterally adopted facilitating practices should be reached under that statute). The Second Circuit panel justified this requirement as necessary to protect respondents against the possibility that the FTC would abuse its power, 729 F.2d at 139, notwithstanding the court's general power to review the rationality of the Commission's determination that the benefits of prohibiting the challenged practices exceed the costs. See 5 U.S.C. $\$ 706(2)$ (1988); see generally E. GELlHoRn \& M. LeVIN, AdMINISTRATIVE LAW AND Process in a Nutshell 105-09 (3d ed. 1990); Boise-Cascade Corp. v. FTC, 637 F.2d 573 (9th Cir. 1980) (overturning an FTC ban on delivered pricing in the plywood industry because the Commission failed to demonstrate that the practice had an anticompetitive effect). 
Even if the Ethyl panel correctly interpreted $\S 5$, its construction of the statute does not necessarily require the Commission to demonstrate an agreement or other indicator of oppressiveness as a prerequisite to banning by rule practices facilitating industry coordination. The strongest argument otherwise is that to permit the FTC to promulgate a rule without such a demonstration would allow the Commission to evade the restrictions imposed by the appellate panel. But this position has repeatedly been rejected by the Supreme Court. The Court routinely permits administrative agencies to regulate conduct by rule without considering certain evidence that the agency would have been required to review had the agency attempted to regulate the identical conduct through adjudication, so long as the agency provides for an exception when a regulated entity can demonstrate extraordinary circumstances requiring a waiver. ${ }^{148}$ Moreover, the Court encourages

148 When adjudication under a statute would require an administrative agency to consider factors $\mathrm{X}$ and $\mathrm{Y}$, the agency may nevertheless promulgate a rule under the statute that permits it to regulate conduct after the examination of factor $\mathrm{X}$ alone, so long as the regulated entity is permitted to seek an exception from the rule on a showing of extraordinary circumstances involving factor Y. American Hospital Ass'n v. NLRB, 111 S. Ct. 1539 (1991) (in reviewing the scope of proposed employee bargaining units in acute care hospitals, the NLRB may promulgate a rule that ignores the size, location and work-force organization of those hospitals save in extraordinary circumstances); Federal Power Comm'n v. Texaco, Inc., 377 U.S. 33 (1964) (agency may promulgate a rule prohibiting across-the-board certain contractual provisions in agreements between gas suppliers and pipelines, while providing the regulated entities with a procedure for seeking a waiver of the rule); United States v. Storer Broadcasting Co., 351 U.S. 192 (1956) (the Federal Communications Commission may limit the television stations owned by any one firm to a specified number, while providing that each regulated firm may seek a waiver of the rule). Indeed, an agency may promulgate a rule that permits it to regulate conduct after the examination of a factor $\mathrm{Z}$ that would not be relevant in an adjudication, so long as the regulated entity can apply for an exception upon a showing of extraordinary circumstances involving factors X and Y. Heckler v. Campbell, 461 U.S. 458 (1983) (the Department of Labor may promulgate a rule for the determination of disability benefits that assesses a person's ability to work from guidelines in part based on age, but does not permit a disabled worker to present evidence of individual competence to perform the jobs for which the guide- 
agencies to issue rules in preference to adjudication in generating agency policy, recognizing that the gains from more efficient governmental administration typically outweigh any reduction in procedural protection to the regulated entities that derives from in effect shifting the burden of proving special circumstances from the agency to those entities. ${ }^{149}$ Consequently, the Commission is likely able to ban by rule practices that facilitate supracompetitive pricing, without the need to satisfy the Second Circuit's requirement for an adjudication that it prove an agreement or other indicator of oppressiveness.

Informal rulemaking offers several advantages to the Federal Trade Commission over adjudication for addressing industry practices facilitating or enhancing oligopoly coordination. ${ }^{150}$ Most importantly, informal rulemaking is likely to be a less burdensome and time-consuming method of enjoining a practice facilitating coordination than adjudication. ${ }^{151}$ In contrast with adjudi-

lines presume an ability; the worker is permitted, however, to offer evidence that the guidelines do not apply to him); Airline Pilots Ass'n v. Quesada, 276 F.2d 892 (D.C. Cir. 1960) (the Federal Aviation Agency may promulgate a rule forbidding individuals 60 and older from piloting aircraft, without permitting each pilot to demonstrate physical fitness and piloting competence; although individual pilots were permitted to seek an exemption, the court suggested that it would have upheld the rule had no exemption procedure been available), cert. denied, 366 U.S. 962 (1961).

149 See generally B. Schwartz, Administrative Law $\$ 4.3$ (3d ed. 1991); accord, Nat'1 Petroleum Refiners Ass'n v. FTC, 482 F.2d 672, 678-85 (D.C. Cir. 1973), cert. denied, 415 U.S. 951 (1974).

150 Agencies receive deference in their choice of whether to employ rules or adjudication, R. PIERCE, S. Shapiro \& P. VerkuIL, Administrative LAW AND PROCEss $\S 6.41$ (2d ed. 1992), even when the resulting rule applies only to a single firm. Hercules Inc. v. EPA, 598 F.2d 91, 118 (D.C. Cir. 1978).

151 Although informal rulemaking can be expensive and take time to complete, it is likely preferable to adjudication on these grounds. The Ethyl litigation took 4 years to resolve at the FTC, between the initial complaint and the final Commission order banning delivered pricing and price protection provisions in contracts with customers. The price-fixing suit brought by several states against the major oil companies, seeking to prohibit the practice of providing advance notice of dealer tankwagon 
cation, in issuing competition rules the Commission need not prove that the firms in the industry have engaged in anticompetitive acts; the FTC may prohibit conduct as unfair when its competitive harm outweighs its benefit. ${ }^{152}$

Yet rulemaking at the Federal Trade Commission has been under a cloud for over a decade. One concern is the large rulemaking record required, the extensive hearing necessary to create such a record, and the length of time required to complete the

prices in trade publications, has not yet reached trial, 7 years after the first complaint in the consolidated proceeding. See In re Coordinated Pretrial Proceedings in Petroleum Prods. Antitrust Litig., 906 F.2d 432 (9th Cir. 1990) (overturning grant of summary judgment to defendants), cert. denied, 111 S. Ct. 2274 (1991). Had these proceedings been framed as informal rulemakings at the FTC, they could not have been more cumbersome and burdensome. (By comparison, a recent general counsel of the Environmental Protection Agency stated that an informal rulemaking would take two years and cost \$2 million dollars. Remarks of E. Donald Elliott, Law and Contemporary Problems Conference on Regulating Regulation: The Political Economy of Administrative Procedures and Regulatory Instruments, Duke University School of Law, Nov. 13-14, 1992.) Moreover, the imposition on informal rulemaking of analytical requirements beyond those originally thought to have been mandated by the APA (such as the judicial insistence on a reasoned explanation for rules beyond the APA's requirement of a concise general statement of basis and purpose), a major source of the increased burden and delay in informal rulemaking throughout administrative practice, does not create requirements more stringent than those imposed on the FTC and the courts when antitrust enforcers seek to prohibit through formal adjudication practices thought to facilitate coordination. See McGarity, Some Thoughts on "Deossifying" the Rulemaking Process, 41 DuKe L.J. 1385, 1400-07 (1992).

152 The substantive content of an informal agency rule is given relaxed review judicially. So long as the rule is reasonably related to the statutory purpose and rationally connected to the factual record, it will not be stricken as arbitrary. B. SchwarTz, supra note 149, at § 4.4; E. Gellhorn \& M. Levin, supra note 147, at 96-102, 113. There is no requirement that the agency adopt the least restrictive alternative in promulgating a rule. B. SCHWARTZ, supra note 149 , at $\$ 4.4$. As discussed at note 135 supra and accompanying text, the FTC likely must also provide a procedure by which the regulated firms could apply for a waiver of the rule upon a showing of extraordinary circumstances. 
rulemaking process. This concern is based upon the Commission's recent experience with promulgating consumer protection rules under a statute that mandates extensive procedural requirements, however, not with the informal rulemaking procedures that would be employed to promulgate rules proscribing unfair methods of competition. The notice and comment procedures available for competition rules are less cumbersome, less complex, and less time consuming than the trial-type hearings required before the FTC may promulgate consumer protection rules. ${ }^{153}$

Three other concerns are also cited by those dubious about the promise of rulemaking as an alternative to adjudication at the FTC. First, industry-wide rulemaking is thought to raise unusually difficult political problems for the agency. These problems arise because the targeted industry can often mobilize congressional support more readily than can the protected class of consumers. ${ }^{154}$ Yet there is no reason to expect the lobbying efforts of the affected industry to be any less if the oligopoly's practices are challenged through adjudication rather than rulemaking. Second, some contend that staff attorneys, concerned about career development, are unlikely to pursue rulemaking passionately because rulemaking will not give them trial experience. ${ }^{155}$ Many attorneys find that other government positions provide rewarding careers without offering trial experience, however. Finally, rulemaking is sometimes thought inappropriate because rules may quickly become outdated in a changing economy. Yet to the extent this concern is not obviated by waiver provisions contained in a rule, it can be addressed by incorporating an "automatic sunset" provision when

153 Consumer protection rules are promulgated pursuant to the Magnuson-Moss Act procedures. The adoption of these procedures has slowed the pace of FTC rulemaking. McGarity, supra note 152, at $1388-40$.

154 Report of the American Bar Association Section of Antitrust Law Special Committee to Study the Role of the Federal Trade Commission, 58 ANTTtRust L.J. 43, 89 (1989).

155 R. Katzman, Regulatory Bureaucracy: Tue Federal Trade ComMISSION AND ANTTTRUST Policy 190-91 (1980). 
a rule is initially promulgated that limits the application of a rule to a specified term of years. ${ }^{156}$

Although these concerns are legitimate, they do not outweigh the benefits of rulemaking in filling the gap in antitrust enforcement to combat the oligopoly problem. If enforcers at the FTC can identify a practice that facilitates coordination, they can address the social harm of oligopoly through rulemaking, without the necessity of proving concerted action to fix price or to adopt the challenged practice. Depending on the facts of an industry, the FTC might prohibit, for example, price protection guarantees to customers, delivered pricing (rather than f.o.b. pricing), or advance announcements of price increases. ${ }^{157}$ The rulemaking inquiry will be fact-based and industry-specific; in other industries the identical practices will be procompetitive.

The ability of rulemaking to address the harmful conduct of oligopolies will turn on the extent antitrust enforcers are able to identify industries performing poorly, ${ }^{158}$ and whether they are able to identify practices that facilitate coordination in such industries. It will not turn on the problem bedeviling adjudication: the need to demonstrate that the firms have reached an agreement to fix price or to adopt the facilitating practice. Of course, it will not always be possible to improve industry performance through rule-

156 Moreover, the concern that rules may become outdated over time is no greater than would apply to an order following an adjudication. Accordingly, this concern does not counsel against adopting competition rulemaking rather than adjudication to address the unreasonable practices of oligopolists.

157 These practices are similar to those challenged by the FTC in the Ethyl litigation, and by the Antitrust Division in the GE-Westinghouse consent modification proceeding.

158 Recent innovations in empirical industrial organization economics may facilitate the task of identifying industries exercising market power. Baker \& Bresnahan, supra note 76 . The Federal Trade Commission has the power to collect industry information through compulsory process in order to apply such tools systematically. 15 U.S.C. § 46(b) (1988); see generally, P. Ward, Federal Trade Commission: LaW, PRActice and ProCEDURE § 11.03[2] (1989). 
making. Even if a practice that facilitates coordination can be identified-and it will not always be possible for enforcers to do so-the benefits to competition from the practice may outweigh the harm. Yet in the context of a legal environment in which the difficulty of demonstrating an agreement under Sherman Act $\S 1$ has increased, and an economic environment in which oligopoly coordination is often plausible, renewed attention to addressing harmful conduct through rulemaking should be high on the antitrust enforcement agenda. 